\title{
Afet Planlamasında Deprem Riski Belirsizliklerinin Değerlendirilmesi
}

\author{
Yasin Fahjan $^{1^{\star}}$, Ferhat Pakdamar ${ }^{1}$, Yaşasın Eryılmaz ${ }^{1}$, F. İlknur Kara ${ }^{1}$ \\ ${ }^{1}$ Gebze Teknik Üniversitesi, Deprem ve Yapı Mühendisliği Anabilim Dalı, 41400, Gebze, Kocaeli.
}

\section{Özet}

Toplumsal yaşamın sürdürülebilirliğini sağlamak, can ve mal kaybına neden olan afetlere karșı direnci artırmak, toplulukları afete hazırlık konusunda bilinçlendirmek ve tüm bileşenleri hazırlıklı bulundurmakla mümkün olabilir. Afet planlaması olası bir afet sonrasında toplumun olumsuz yönde etkilenmesini azaltmak ve kaynakların doğru kullanım hedeflerini gözeten bir yaklaşımdır. Ülkemizdeki kayıplarda da önemli bir yere sahip depremin risk değerlendirmelerinde deterministik ve olasllısal yöntemler olmak üzere iki temel yaklaşım bulunmaktadır. Bu çalışmada deprem risk değerlendirmesine, yer hareketi, yapı envanteri ve yöntem bileșenlerinde mevcut olan belirsizliklerin etkisi araştırılmıştır. Çalışmada, Marmara bölgesinin önemli fay hatlarına yakın ve Kocaeli Depremi (1999) şiddetinin en fazla hissedildiği yerleşimlerden biri olan Gebze (Kocaeli) ilçesi seçilmiş, deprem senaryolarlyla risk yapısı değerlendirilmiştir. Senaryo depremleri uygulanırken depremin kaynağl, depremin büyüklü̈̆̈̈ ve zemin parametrelerinin riske etkisi incelenmiştir. Risk değerlendirmeleri sonuçlarına göre bina hasarl, can kaybı ve barınak ihtiyacı oranları hesaplanmıştır. Ayrıca mahalle bazında beklenen şiddet, hasar seviyeleri zemin etkisinin dikkate alındı̆̆ ve alınmadığl durumlar için harita üzerinde ayrı ayrı gösterilmiştir. Bu değerlendirmeler ülkemiz için hazırlanmış sismik tehlike bilgisi, yerel zemin bilgisi ve bina envanterindeki unsurları içeren veriler ile CBS verilerini birleştirebilen ön hasar tespit yazılımı, AFAD-RED kullanılarak gerçekleștirilmiștir. Sonuç olarak, deprem risk planlamasında yer hareketi tahmin belirsizliklerinin kayıp tahmini sonuçları üzerindeki önemi gösterilmiştir.

Anahtar Sözcükler

Doğal Afetler, Deprem, Afet Planlama, Risk Değerlendirme.

\section{Uncertainties in Earthquake Risk Assessment for Disaster Planning}

\begin{abstract}
To obtain the sustainability of social life and to increase resistance to disaster that cause loss of life and properties; it is possible to raise awareness in the community about disaster preparedness and engross to take all the components. Disaster planning is an approach that targets the correct use of resources to decrease negative impacts in the community after the disaster. In Turkey, earthquake losses have an important role in disaster planning. There are two basic approaches for earthquake loss estimation used in disaster planning namely deterministic and probabilistic. Uncertainties of the seismic risk assessment parameters can be generated from ground motion computations, structural inventories and risk methodologies. In this study, uncertainties in the ground motion estimations are investigated. Gebze district that located close to major fault lines at Marmara region, and had significant damage during Kocaeli earthquake (1990), is selected as a study case for the risk assessment scenarios. The uncertainties parameters in ground motion computation that have major effect on the risk assessment are considered as earthquake source, earthquake magnitude and soil parameters. As a result, building damage ratios, loss of life and the need for shelter are computed. The soil amplification effects on the seismic intensity level and damage ratios are emphasized. The earthquake hazard estimation and risk assessment computation were performed utilizing geographic information system based software AFAD-RED. The software combines the scenario based seismic hazard procedure with the existing building inventories and soil data for the risk estimations. As a result, it is concluded that, uncertainties in ground motion computations have important effect on the seismic risk assessment and should be considered in disaster planning process.
\end{abstract}

$\underline{\text { Keywords }}$

Natural Disaster, Earthquake, Disaster Planning, Risk Assessment.

\section{Giriş}

Dünyada meydana gelen deprem, sel, firtına, kuraklık yangınlar vb. afetlerde her geçen gün daha fazla can ve mal kaybı ile karşılaşılmaktadır. Sadece 2002 yılında, meydana gelen 500'den fazla afet 10.000'in üzerinde can kaybı oluşmuş, 600.000.000'dan fazla kişi etkilenmiş, 55 milyar \$ değerinde hasar ve 13 milyar \$ sigorta kaybı oluşmuştur. \%90'dan fazlası kaynakları sınırlı ve gelişmekte olan ülkelerde olmak üzere her yıl 70-80 milyon kişi giderek artan şekilde afet riskiyle karşılaşmaktadır (ISDR 2004).

\footnotetext{
* Sorumlu Yazar: Tel: +90 (262) 6532197 Faks: +90 (262) 6051652

E-posta: fahjan@gtu.edu.tr (Fahjan Y), pakdamar@gtu.edu.tr (Pakdamar F), eyasasin@gtu.edu.tr (Eryılmaz Y), figokce@gtu.edu.tr (Kara F.I)
} 
17 Ağustos ve 12 Kasım 1999 tarihlerinde ülkemizde meydana gelen iki büyük doğal felaket sonrasında önemli ekonomik ve sosyal kayıplar oluşmuş ve oluşan zararlarının önlenebilmesi ya da en azından azaltılabilmesi amacıyla, yerel yönetim, devlet kurumları, sivil toplum kuruluşları ve akademik çevrelerce deprem risk analizlerine dayanan, afet müdahale planlarının hazırlanması gereği önemli bir gerçek olarak ortaya çıkmıştır. Bu çalışmada özel olarak deprem sonrası uygulamaya konulacak afet müdahale planlamasının deprem risk analizlerindeki belirsizliklerin etkisi incelenmektedir.

Afet planları, en alt seviyeden, üst seviyeye kadar, sırasıyla olay, acil durum ve afetler için gerekli olduğunda faaliyete geçirilmesi amacıyla hazırlanan planlardır. Planlama, tehlike oluşmadan önce uygulanan çalışmalardır ve üç basamaktan oluşmaktadır: 1. Şimdiki durumu, mevcut kaynakları ve bulunabilecek kaynakları belirlemek, 2 . Hedefleri belirlemek ortaya koymak, 3. Bir afet anında yapılacak işlerin tespit etmektir (Ișık vd. 2012)

Olası bir afet sonrasında kayıpların azaltılabilmesi afet planlaması ile mümkündür. Risklerin oluşturabileceği olası hasarların önlenebilmesi için; risklerin saptanması, saptanan bu risklerin tümünün değerlendirilmesi ve bu risklere karşı tedbirlerin geliştirilmesi gerekli evrelerdir. Başarılı bir afet yönetimi, afet öncesi riskleri değerlendirip yapılacak çalışmaların ve uygulama evrelerinin nasıl, kimler tarafından yapılacağının saptandığı, afet sonrasında ise toplumun olumsuz yönde etkilenmesinin azaltılması ve kaynakların doğru kullanımının sağlanması hedeflerine yaklaştıkça gerçekleştirilebilir. Tüm afet olayları ile ilgili etkinlikler, dört temel evrede belirlenmektedir:

1. Zarar azaltma,

2. Hazırlıkli olma,

3. Olaya müdahale,

4. İyileştirme (Işı1k vd. 2012).

Zarar Azaltma: Olası afet durumları için can ve mal kaybı zararlarını bertaraf etme hedefiyle yapılan faaliyetler ve alınan tedbirleri içermektedir. Bu nedenle kentsel dönüşüm kararları; afet planlaması değerlendirmelerinde, afet öncesi zarar azaltımı evresinde alınmalıdır (Özçevik vd. 2007).

Hazırlıklı Olma: Olası bir afet durumunda yetki ve sorumlulukların belirlenmesi ve yardım sağlayacak ögelerin belirlenmesini kapsamaktadır.

Olaya Müdahale: Afet sonrasında, kayıpları azaltmak ve kurtarmak için yapılan tüm aktiviteleri içerir.

İyileștirme: Fiziki ve sosyal çevrede, altyapıda, felaket sonucunda oluşan hasarların düzeltilerek, toplumsal yaşamın normale dönmesi için yapılan uğraşları kapsar (Türkoğlu 2014).

Afet yönetiminin başarısı toplumun tüm kurum ve kuruluşlarının kaynaklarını ortak amaçlar doğrultusunda kullanmaları ile sağlanabilir (Şekil 1). Afet yönetimi, olası bir afete karşı hazırlık stratejilerinin belirlenmesi, oluşan bu afet sonrasında belirlenen stratejilerin uygulanması, afetin olumsuz sonuçlarının önlenmesi veya azaltılması olarak da tanımlanabilir. Bununla beraber afet yönetimi risk azaltma faaliyetleri ile ilgili uzun dönemli ve kapsamlı tedbirlerin değerlendirilmesi ve uygulanması çalışmalarının yönetilmesini de kapsamaktadır. Afet yönetimi açısından risk; tehlike, savunmasızlık ve maruziyet kavramlarının bir bileşkesidir (Kundak 2014). Bu nedenle afet riski taşıyan ülkeler için afete hazırlıklı olmak, afetin olası zararlarını azaltmada önemli evrelerden biridir.

Tüm Bireyler / Birimler

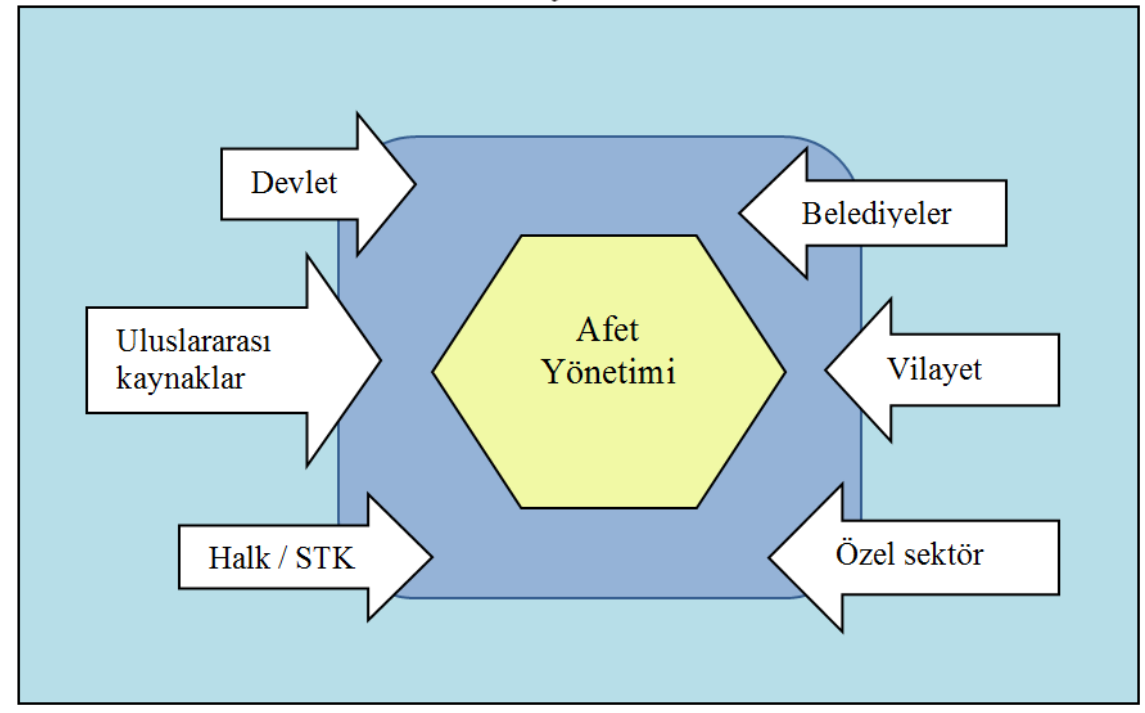

Şekil 1: Afet yönetimi bileşenleri (Işık vd. 2012).

Afet riski önlenemiyorsa zararın azaltılabilmesi için önceden hazırlıklı olmak gerekmektedir. Burada amaç, afet anında ve sonrasında yaşanabilecek olan kayıpların en aza indirilmesidir. Önceden hazırlıklı olmak afet anında devreye 
girecek komuta sisteminin oluşturulması, doğru planlama yapılması, afetlerin tahmin edilip erken uyarı sistemlerinin oluşturulmaya çalışılması, tatbikatlar yapılması ve eğitim verilmesiyle mümkün olmaktadır.

Birçok belirsizlik içeren afetlerle baş edebilme kapasitesini artırmak, tüm bireyleri ve toplulukları afete hazırlık konusunda bilinçlendirmekle ve tüm afet yönetim bileşenlerinin hazırlıklı olması ile mümkün olabilir. Afet yönetimi sisteminin doğru yerlere doğru "müdahale" yapabilmesi için afet öncesi çalışmaların itina ve yeterli şekilde yerine getirilmesi gerekir (Gerdan 2014).

BM'nin Uluslararası Felaket Azaltma Stratejisi'ne göre risk, tehlikelerin hasargörebilirlik ile birlikte değerlendirilmesiyle hesaplanabilir (Denklem 1). Risk, hasargörebilirlik ve afetin büyüklüğü ile doğru orantılıdır. Riskin etkisi; insan kaynaklı afetlerin azaltılması ve hasargörebilirlik (sosyal faktörler) düzenlenmesi ile mümkündür (ISDR 2004).

\section{Risk $=$ Tehlike $X$ Hasargörebilirlik}

Risk, doğal veya insan kaynaklı tehlikeler ve savunmasız, hasar görebilir çevreler arasındaki etkileşimin sonucu olarak ortaya çıkan zararın veya muhtemel kayıpların ihtimali (can, mal, çevre, tarihi miras, iş vb.) olarak tanımlanabilir. Riskin iki bileşeninden biri olan tehlike, doğal bir olgu olarak veya insan kaynaklı hayat kaybı, yaralanma, maddi hasar, sosyal ve ekonomik bozulma veya çevresel bozulma şeklinde ortaya çıkması muhtemel zarar verici fiziksel olaylar (yer sarsıntısı, yüzey faylanması, sıvılaşma, artçı sarsıntılar, toprak kayması, sel, tsunami, yangın vb.)olarak tanımlanır. Riskin ikinci bileşeni olan hasargörebilirlik ise tehlikenin etkisi hakkında bir topluluğun duyarlılığını artırmak için fiziksel, sosyal, ekonomik, çevresel etkiler ve süreçler tarafindan belirlenen koşullar (hızlı ve kontrolsüz kentleşme, uygun olmayan fiziksel yaşam koşulları, yetersiz altyapı, hatalı planlama, inşaat ve kontrol eksiklikleri, çevre bozulması, eğitim eksikliği vb.) olarak tanımlanabilir (ISDR 2004).

\section{Kentsel Risk Yönetimi ve Sakınım Planı İlişkisi}

\begin{tabular}{l}
\hline RiSK (SONUÇ) \\
\hline \hline \\
\hline - Yaşam \\
- Sağlık \\
- Emeklilik ve Sosyal Yardım \\
- Mülk \\
- Çevre \\
- Miras \\
- İs \\
- Hizmetler \\
- Kalkınma \\
- .......
\end{tabular}
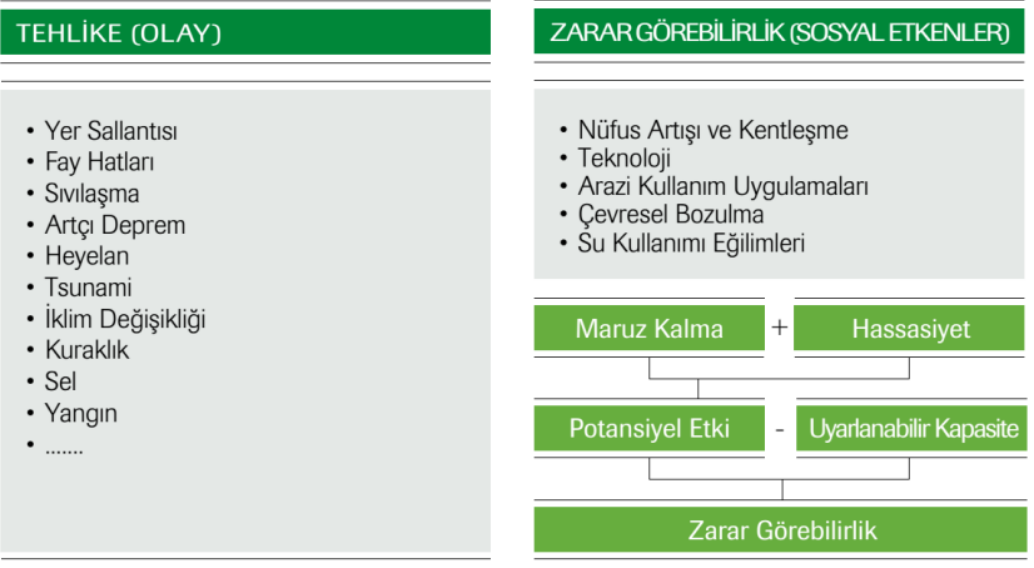

Şekil 2: Kentsel risk yönetimi (Kundak 2014; Türkoğlu 2014)

Risk hesabı için literatürde bulunan ve olasılık içeren diğer bir formülasyon (Tsai ve Chen 2010) ;

$R=O \quad x \quad E \quad x \quad S$

şeklinde verilebilir. Burada,

R: Risk

O: Felaketin-tehlikenin oluşma oranı,

E: Afetten etkilenen kişi veya varlıkların sayısı,

S: Hasargörebilirlik-Hasar Seviyesi, şeklindedir.

Afet yönetimi sistemi; birbirini tamamlayan, iki farklı yönetim düzeninden oluşmaktadır;

a) Zarar Azaltma (Risk) Yönetimi, b) Acil Durum (Kriz) Yönetimi. 
Afet Yönetiminin Evreleri

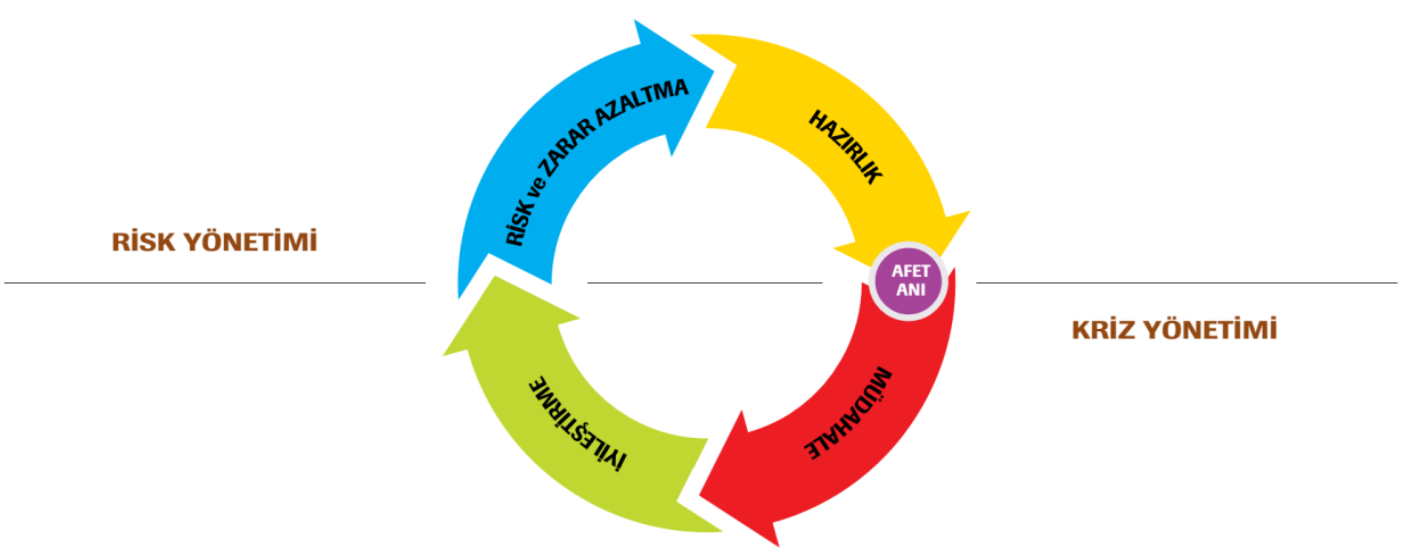

Şekil 3: Afet yönetiminin evreleri (Türkoğlu 2014).

Afet Yönetimi (Şekil 3); afet öncesi ve afetten sonra yapılacak faaliyetleri, bu faaliyetlerin yürütülmesi için afet öncesi örgütlenmeyi, lojistik hizmet ve haberleşmeyi içeren hazırlıkların hepsini içermektedir (İBB 2009; Türkoğlu 2014). Kriz, bir afet sonrasında geçirilen zor ve buhran dönemi olarak tanımlanırsa bu buhran dönemini düzeltmeye ve en hafif şekilde atlatmaya yönelik çalışmalara ise kriz yönetimi adı verilebilir. Kriz yönetiminde toplumun en az kayıpla üretkenliğini sürdürebilmesi, önceliklerin belirlenerek kapasite artırımının sağlanabilmesi, ilk aşamada üretimin yapılıp yapılmaması veya farklılık içermesi kararı alınmaktadır. Risk Yönetiminde ise, afet öncesinde olası zararlar tanımlanarak, risk bölgeleri ve risk yoğunluğunun saptanması ve alınacak tedbirler ile zararları azaltmak hedeflenmektedir. Risk Yönetimi planlaması "Olasılık Senaryolarına Sahip Planlama" ile yerleşim bölgelerinde oluşabilecek hasarlar önceden saptamaya çalışılmaktadır. Risk Yönetimi'nde uygulanan asıl kural "Yara Almama" stratejisidir. Böylece olası riskler etkin bir şekilde ve az masrafla hafifletilebilir (Balamir 2000). Yüksek riskli yerleşim yerlerinde ve farklı risk sektörlerinde risk yönetimi tipinin belirlenmesi, sektörler arası uyumun sağlanması, yerel yönetimlerin imar planları ve revizyonlarında yerel yönetimlerin riskli bölgelerde yapacağı uygulamalar için araçlar geliştirilmesi, riski önleyecek tedbirlerin alınması ve sürekli denetim yapılması kentsel riskin azaltılmasında temel düzenlemeler (Şekil 2) olabilir (Balamir 2004; Ersoy 2012).

$\mathrm{Bu}$ çalışma kapsamında deprem felaketi için risk ve afet yönetimi konuları incelenmiştir. Ülkemizi en fazla etkileyen doğal felaketlerden olan depremler ortalama olarak iki yılda bir (Kızılkanat vd. 2011) yapısal hasarların üçte ikisine, can ve mal kayıplarının da önemli bir kısmına yol açtığı (Tercan 2005), deprem riski yüksek olan yerlerde bile yerel tehlike haritaları (mikro-bölgeleme haritaları) hazırlanamadığı için (Genç 2007), afet yönetimini gerektiren en önemli tehlike olduğu (Akıncıtürk 2003) görülmektedir. Deprem afeti sonrasında meydana gelen can ve mal kayıplarının büyük bir kısmı; binaların deprem performansı ile ilişkili hasarlara bağlı olarak oluşmaktadır. Ülkemizde sismik tehlikenin yüksekliği, olası kayıpların önlenebilmesi için tedbir almayı gerekli kılmaktadır. Bu nedenle afet yönetiminde; depreme dayanıklı yapı tasarımı, bina stoğunun deprem güvenirliğinin belirlenmesi, hasar ve kayıp tahmini çalışmaları ve depremin şiddet etkilerinin azaltılması öncelikli konulardır (Taşkın vd. 2014).

Deprem tehlikesi veya zararı ile anlatılmak istenen şey genellikle insanların yoğun olarak yaşadıkları yerleşim merkezlerinde bir deprem sonrasında oluşabilecek hasar ve kayıplardır. Deprem riski oluşabilecek bu hasar ve kayıpların istatistiki bir yaklaşımla deprem olmadan önce kestirilebilmesini, öngörülmesini ifade etmektedir. Aynı bölgedeki iki yerleşim birimi için olası deprem tehlikesi değişmezken, olası deprem riski çok farklı sonuç verebilir. Yerleşim bölgelerindeki yapı ve yaşayan insan sayısının artması, bir felaket anında olası can ve mal kaybını yükselteceği için, risk de orantılı olarak artmaktadır. Bu nedenle deprem tehlikesine karşı yerleşim bölgelerinde alınacak önlemlerde hem deprem özellikleri, hem de yapısal karakteristikler belirlenmeli ve aralarındaki ilişki sistematik biçimde ele alınmalıdır (Balyemez ve Berköz 2005).

Ülkemiz deprem kuşağında olmasına karşın geçmiş depremler bu felakete karşı hazırlıksız olduğumuzu kanıtlamıştır. Depremler afet anında sebep oldukları can ve mal kayıplarına ek olarak uzun vadede üretimde düşüşlere, ekonomik olarak olumsuzluklar yaşanmasına ve kayıpların artmasına neden olmaktadır. Bu afete karşı başlıca tedbir zemin özelliklerini dikkate alan, uygun arazi kullanımı kararlarının alınarak afete duyarlı bir planlama yapılmasıdır. (Akıncitürk 2003)

Türkiye'de sanayi bölgelerinde yaşanan depremler (Adana-Ceyhan 1998; Kocaeli ve Düzce 1999) sonrasında yapılan incelemelerde, prefabrik betonarme sanayi yapıları başta gelmek üzere, yapılarda deprem performansı yönünden önemli derecede kusur bulunduğu saptanmıştır. Marmara bölgesinin, ülkemizdeki sanayi yapıları açısından en yoğun bölge olması ve yüksek derecede deprem riski taşıması (yıllık \%2) nedeniyle tehlikenin boyutları artmaktadır (Eren 2014). 


\section{Deprem Riski Değerlendirme Yöntemleri}

Deprem riski hesaplamalarında deterministik ve olasılığa dayalı yöntemler (Şekil 4) karar verme süreçlerinde birbirini tamamlayıcı önemli işlevlere sahiptir. Deterministik yöntemlerde aktif bir fayın oluşturabileceği kuvvetli yer hareketleri büyüklükleri saptandıktan sonra; ivme genlikleri ve deprem merkezinden uzaklığına göre azalım ilişkileri hesaplanmakta ve yerleşimlerdeki yüzey ivme değerleri ve genlikleri zemin özellikleri düşünülerek hesap yapılmaktadır. Daha sonra, yüzey ivme genlikleri ile yapı periyotlarına göre kayıp ve hasar, yapı davranış modellemesi ile tahmin edilmektedir.

Olasılıksal deprem tehlikesi hesaplarında ise hasar oluşturabilecek yer hareketinin bölgesi ve saptanmış zaman aralığ 1 döneminde gerçekleşme olasılığı dikkate alınmaktadır. Sonraki evrelerde deterministik metot kuralları uygulanır. Risk azaltma, sismik ortam ve projenin yapılış amacına bağlı olarak hesaplama türü kararı verilebilir. Deprem Riski azaltma amacıyla kullanılacak en uygun çalışma, hem deterministik hem de olasılıksal analizlerin birlikte yapılmasıyla sağlanabilecektir (Çavuş ve Akyol 2015; McGuire 2001).

Belirli bir yerleşim yerinin küçük bir parçası için veya jeo-hücresel risk tahmininde olasılıksal yaklaşım ile muhtemel kayıpları belirlemek uygun olabilir. Fakat kentsel can damar sistemlerine gelecek hasarların öngörüsü için üç boyutlu sistem tabanlı yaklaşımların kullanılması gerekmektedir. Bu tür değerlendirmelerde olasılık yaklaşımı yetersizdir (Erdik vd. 2003). Bununla birlikte yerleşim bölgelerindeki hasar değerlendirmeleri ve öngörüleri için deterministik yaklaşımda senaryo depremi (veya deprem takımları) kullanımı geleneksel bir hal almıştır. Senaryo depremi, genel riske en çok etkisi olan kaynağı bulabilmek için olasılıksal deprem risk yaklaşımının ayrıştırılması olarak tanımlanabilir (Faccioli ve Pessina 2003; Somerville ve Moriwaki 2003; Thenhaus ve Campbell 2003). İlk olarak 1998 yılında (Whitman ve Lagorio) çıkarılan HAZUS (2010), Amerika Birleşik devletleri için standartlaştırılmış bir deprem kayıp tahmin metodolojisi olmakla birlikte; risk, tehlike ve hasargörebilirlik değerlendirmesi maliyet ve kayıpların niceliksel tahmini bakımından da oldukça kapsamlıdır.

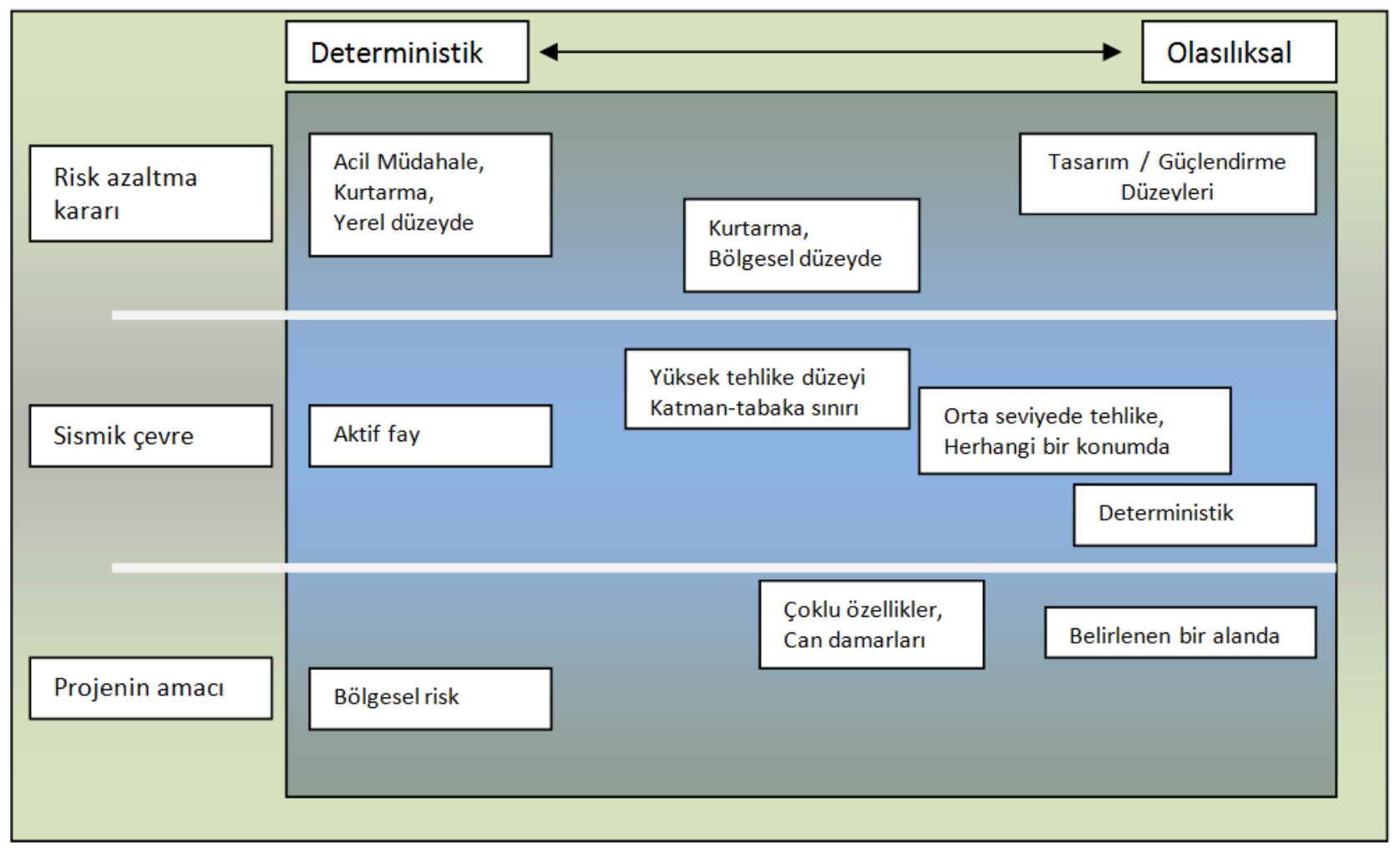

Şekil 4: Deterministik ve olasılıksal yaklaşım aralığında sismik risk uygulamaları (McGuire 2001).

Tehlike ve Senaryo Depremi: Deprem tehlike değerlendirmesi için çok detaylı çalışmalar, çeşitli yöntem ve değerlendirmelerle yapılmaktadır. Bununla birlikte, en genel yöntem deprem dönüş periyodu veya depremin aşılma olasılı̆̆ 1 için hesaplanan en büyük yer hareket parametrelerini (en büyük ivme, spektral ivme ve şiddet) bir harita üzerinde gösteren eğrileri oluşturmak şeklindedir. Yapılacak bir deprem afet yönetimi çalışması için öncelikle bölgenin fay yapısını incelemek ve bu fayların oluşturabileceği depremleri tespit etmek gerekir. Şekil 5'de örnek olarak Kuzey Anadolu Fay Hattının Marmara Bölgesi’ndeki segmentleri görülmektedir (Erdik vd. 2004). 


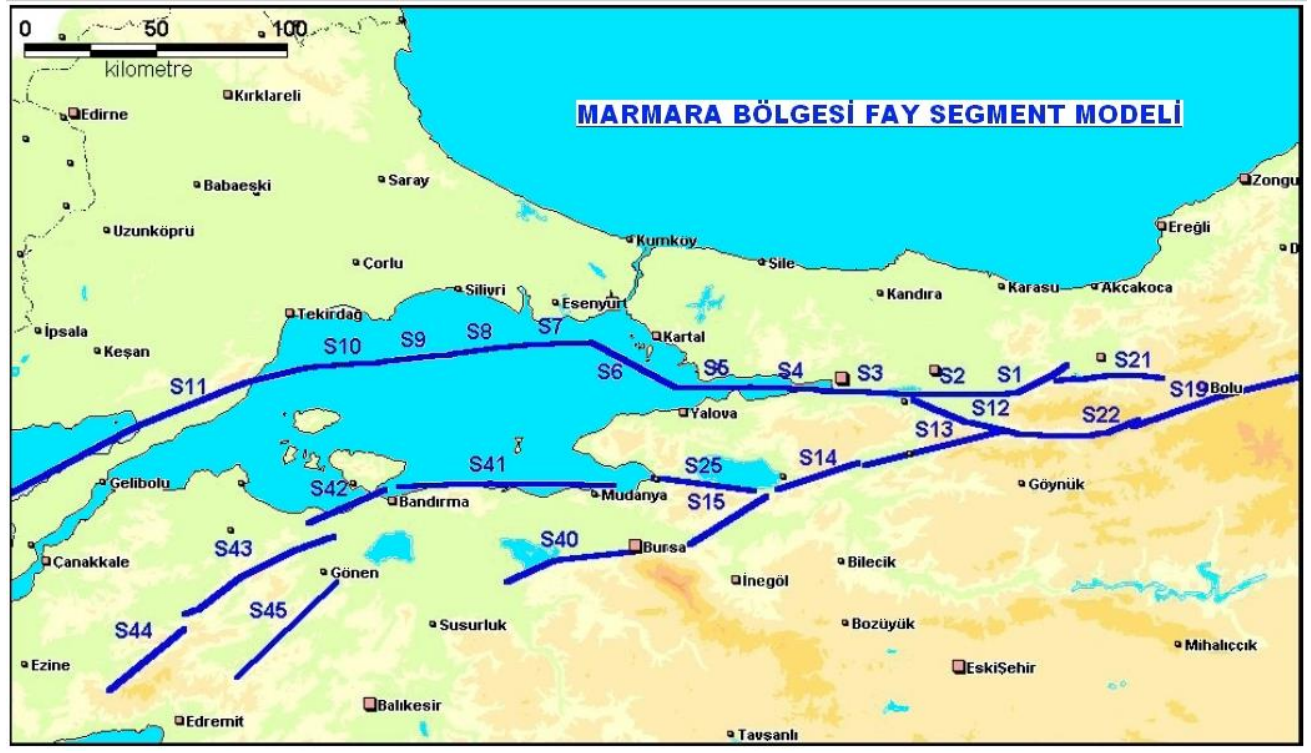

Şekil 5: Marmara bölgesinde fay segment modeli (Erdik vd. 2004).

Azalım İlişkileri: Azalım ilişkileri genellikle, "M" büyüklüğündeki bir deprem yer hareketinin, "R" uzaklığındaki bir noktada jeolojiye bağlı olarak yaratacağı en büyük zemin hareketi parametresinin değerini veren fonksiyon olarak tanımlanmaktadır. Uzaklık olarak daha çok, dışmerkez ya da sismik kaynaktan ölçülen farklı tanımlamalara sahip mesafeler esas alınmaktadır. Araştırmacılar, yeryüzünün değişik bölgeleri için geçerli olacak azalım ilişkileri önermişlerdir. Günümüzde kullanılan azalım ilişsilerinin birçoğu deprem ile ilgili mühendislik hesaplarında yer ivmesinin çok önemli rol oynaması nedeniyle farklı periyotlara karşılık gelen spektral ivme genliklerinin (PGA, PGV, PGD) hesaplanmasina dayanmaktadır.

İvme Azalım İlişkileri: Aletsel dönemde meydana gelmiş ve ivme kayıtları da alınmış depremlere ait deprem parametreleri de gözetilerek, farklı ülkelerde ve farklı araştırmacılar tarafından derlenmiş veri tabanları kullanılarak yapılan istatistiksel analizler sonucunda ivmenin kestirimi (tahmini) amacıyla geliştirilmiş eşitliklerdir. Günümüze kadar önerilmiş 120 'den fazla ivme azalım ilişkisi bulunmaktadır (Douglas 2003). Ancak bu eşitlikler, farklı deprem bölgeleri, fay türleri, plaka içi ya da plakalar arası gibi durumlar için geliştirilmiştir. Bu eşitliklerin geliştirilmesinde kullanılan veri tabanının seçimi için değişik kıstaslar kullanılmasııın yanı sıra, sadece kaya ya da sıkı zemin gibi tek bir zemin türü dikkate alınarak ivme azalım ilişkileri geliştirilmiştir.

Azalım ilişkileri; deprem büyüklüğü, mesafe (kaynağa uzaklık), faylanma mekanizmasına ve yerel saha koşullarına da bağlı olarak değişmektedir. Literatürde bazı azalım ilişkilerinin, zemini yumuşak ve sert/kaya olmak üzere sadece iki genel sınıfa ayırmakta olduğu (Abrahamson ve Silva 1997; Ambraseys vd. 1996; Sadigh vd. 1997) ve zemin parametresini ifade eden tek bir değişkene yer verildiği görülmektedir. Zemin türünü kayma (makaslama) dalgasına bağlı olarak ifade eden azalım ilişkileri (Boore vd. 1997; Kalkan ve Gulkan 2004) ise, zemin etkisini daha kapsamlı bir şekilde dikkate almaktadır. Çoğu deprem kayıp senaryo uygulamalarında sıvılaşma hassasiyeti; jeoteknik ve jeomorfolojik kriterlere göre değerlendirilmektedir (Youd 1991; Youd vd. 1978; Youd ve Perkins 1978).

Şiddet Esaslı Hasargörebilirlik İlişsileri ve Belirsizlikler: Şiddet esaslı hasargörebilirlik ilişkileri, geçmiş deprem hasarlarının istatistiksel değerlendirilmesine dayanmaktadır. Genel olarak, şiddet esaslı deprem hasar tahmin çalışmalarında, yer hareketlerini ifade etmek için (Değiştirilmiş Mercalli-MMI veya Avrupa Mikrosismik-EMS'98) Şiddet Ölçeği gibi) makrosismik şiddet ölçekleri kullanılır. Dünyanın çeşitli bölgeleri ve yerel yapı sınıfları için şiddet esaslı hasargörebilirlik ilişkileri elde edilmiştir. Bu ölçekler farklı yapılardaki hasarlarla doğrudan ilişkili olduğundan geçmiş depremler için çoğu zaman gerçekçi sonuçlar verir. Ancak, gelecekte olacak depremler için zemin davranışının da etkin olduğu deprem şiddetini tahmin etme ve hasar-can kaybı ilişkisinin yaklaşı olarak hesaplanması nedeniyle kullanım durumları sınırlıdır. Hasargörebilirlik eğrilerinin oluşturulmasında kullanılan şiddet ölçeğindeki belirsizliklerden biri depremin büyüklüğü yani manyitüdü diğeri ise zemin sınıfıdır.

$\mathrm{Bu}$ çalışmada şiddet esaslı hasargörebilirlik ilişkilerinin çıkarılmasında Avrupa Mikrosismik Şiddet Ölçeği (EMS'98) kullanılmıştır. EMS'98 ve hasargörebilirlik arasındaki ilişkileri örnek olarak (Rossetto ve Elnashai 2005) gösterilebilir. Betonarme binalar için hasar sınıfları beş seviye olarak (Şekil 6) belirlenmiştir (Erdik vd. 2003):

D1: İhmal edilebilir hafif yapısal hasar (SD), Hafif yapısal olmayan hasar (N-SD);

D2: Orta hasar (Hafif SD, Orta N-SD);

D3: Önemli ağır hasar (Orta SD, Ağır N-SD);

D4: Çok ağır hasar (Ağır SD, Çok ağır N-SD)

D5: Yıkım. 


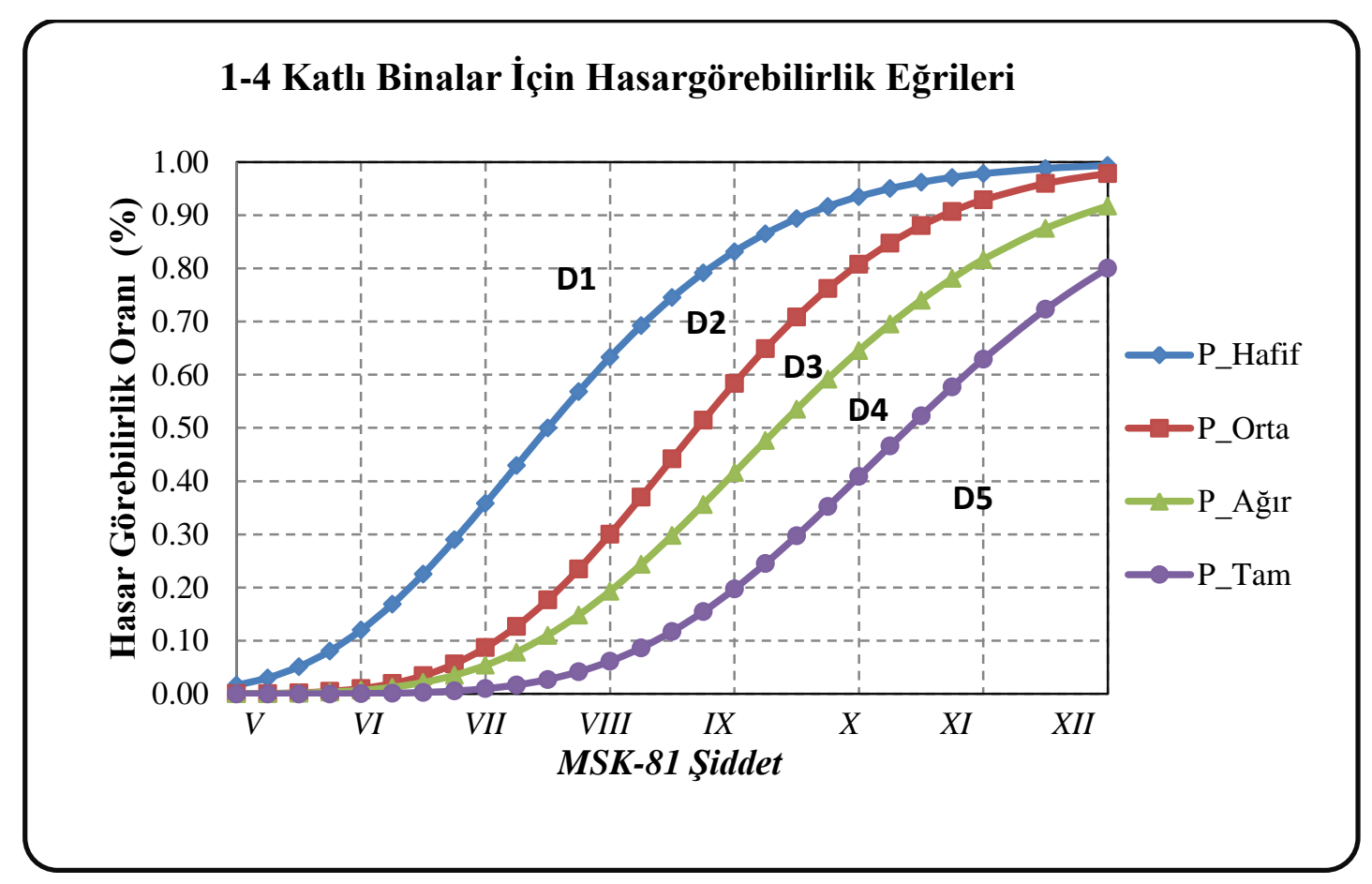

Şekil 6: Türkiye genelindeki az katı (1-4 katı) betonarme yapılar için MSK-81 şiddet cetveli kullanılarak hesaplanan hasargörebilirlik eğrileri (Erdik vd. 2003).

Görüldüğü üzere olası bir deprem sonrasında uygulanacak afet yönetimi için yapılan deprem risk analizleri birçok belirsizlik içermektedir. Depremlerin konumunu, oluşma mekanizmasını, ne zaman ve nerede hangi büyüklükte olacağını şimdiki teknoloji ile tahmin etmek mümkün değildir. Ayrıca hasar durumlarının tanımlanabilmesi, verilerin ve sonuçların doğru yorumlanabilmesi için yapı stoku ve karakteristik özelliklerini içeren bir yapısal sınıflandırma sisteminin oluşturulması, risk analizlerinde gerekli ve önemli bir adımdır. Yapısal parametreler (taşıyıcı sistem, yükseklik, vb.), yapısal olmayan elemanlar ve binanın kullanım amacı (konut, ticari amaçlı ve resmi binalar) hasar ve can kaybını önemli ölçüde etkilemektedir. Bu çalışma kapsamında tüm bu belirsizliklerden; deprem büyüklüğü ve zemin etkisi, afet yönetimi açısından incelenmiştir.

\section{Gebze İlçesi İçin Risk Tahmin Analizleri}

Marmara Bölgesi ülkemizin ekonomik ve sosyal yapısı açısından çok önemli bir role sahiptir. Bölgede tarihsel süreç incelendiğinde ise yıkıcı depremlerin etkin olduğu görülmekte ve sürekli deprem aktiviteleri meydana gelmektedir. İnceleme bölgesi olarak seçilen Kocaeli’ne bağlı Gebze ilçesi; 9 tane organize sanayi bölgesi ve 2.000'den fazla sanayi kuruluşu ile Marmara bölgesi için ayrı bir önem arz etmektedir. Bu çalışma kapsamında deprem tehlikesi analizlerindeki belirsizliklerin deprem risk analizine olan etkilerini değerlendirmek amaciyla; Gebze için olası senaryolarla deprem risk analizleri yapılmıştır. Analizler, Marmara bölgesinde bulunan üç farklı fay mekanizması, farklı büyüklükte depremler oluşturacak şekilde kırılarak yapılmış, deprem risk analizlerinde zemin etkisinin hesaba katılması ve katılmaması durumları incelenmiş ve her bir seçenek için beklenen bina hasar durumları, can kayıpları ve barınak ihtiyacı oranları belirlenmiştir.

Deprem risk ve ön hasar tahmin çalışmaları hesaplamalarında T.C. Başbakanlık AFAD için geliştirilen (Fahjan vd. 2015; Nurlu vd. 2014) AFAD-RED yazılımı kullanılmıştır. Bu yazılım modülü sayesinde; ülkemizde meydana gelen bir deprem sonrasında hızlı kayıp tahmini yapılabilmekte ve şiddet haritaları (shake maps) oluşturulabilmektedir. Türkiye için AFAD-RED, AFAD Deprem Dairesi tarafından işletilen deprem gözlem istasyonlarından elde edilen deprem parametrelerini ve mevcut bina ve nüfus veri tabanını kullanarak; belirlenmiş bir deprem için oluşabilecek can kayıplarını ve bina hasarlarını tahmin edebilmektedir (Şekil 7).

Çalışmanın ilk aşamasında 17 Ağustos 1999 Marmara Depremi senaryo deprem olarak seçilmiş ve mevcut hasar ve can kaybı verileri AFAD-RED yazılımı ile yapılan hasar tahmin sonuçlarıyla karşılaştırılmıştır. AFAD-RED analiz sonuçlarının değerlendirildiği 17 Ağustos depremi sonrasında hazırlanan deprem raporuna göre Gebze'de 48 can kaybı yaşanmıştır, 1.162 binada ağır, 3.149 binada orta hasar meydana gelmiştir (Özmen 2000). 


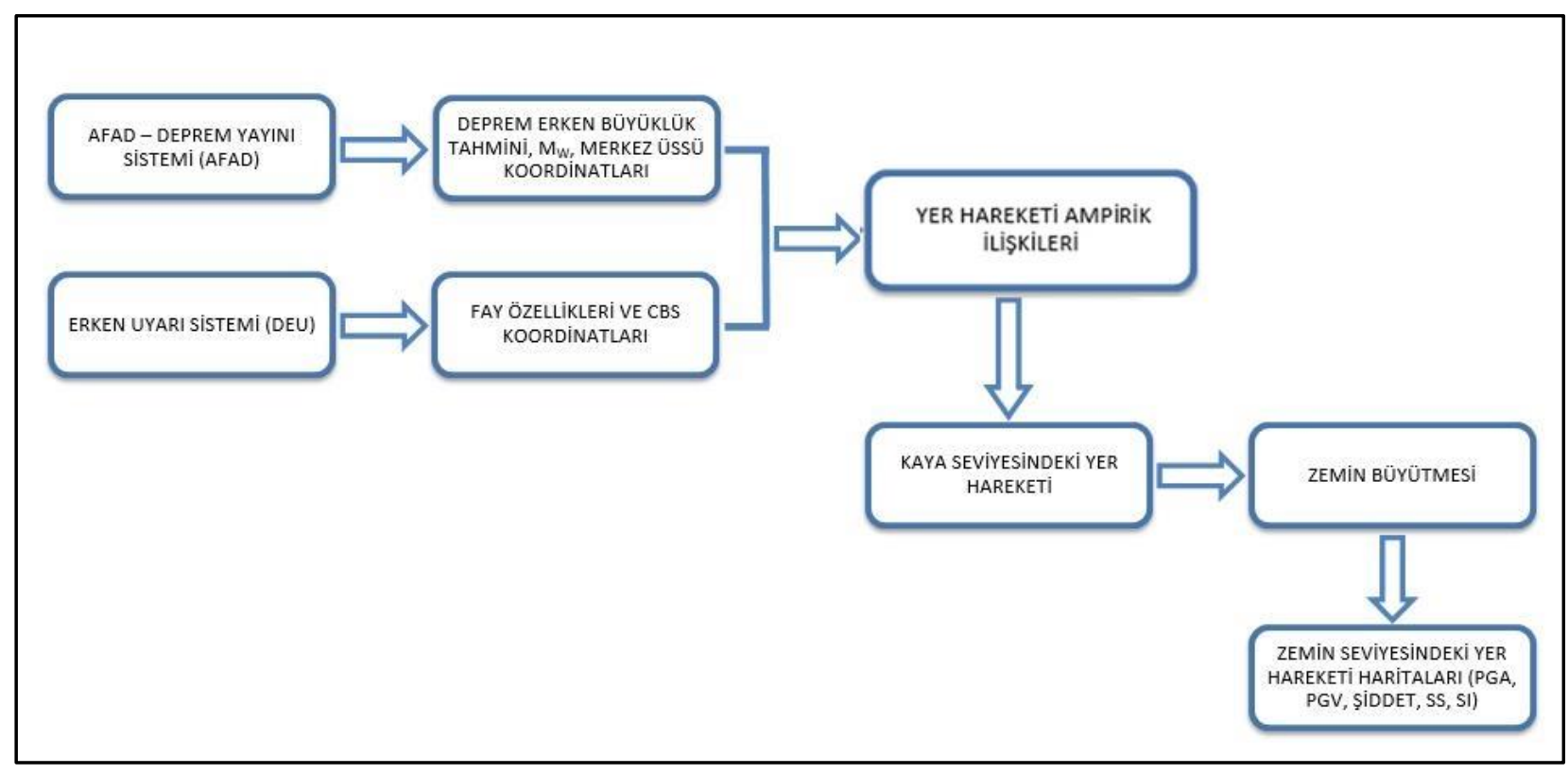

Şekil 7: AFAD-RED'in yer hareketi tahmini akış şeması

AFAD-RED yazılımı ile 17 Ağustos depremi için yapılan ön hasar tahmin sisteminde Gebze'de 61 can kaybı yaşanacağı, 1072 binada ağır, 3542 binada ise orta hasar meydana geleceği tahmin edilmiştir. Hesaplamalarda, 1999 yılında Gebze'ye bağlı yerleşimler olan Darıca, Çayırova ve Dilovası'nın; 2008 yılında Gebze'den ayrılarak Kocaeli'ne bağlı yeni ilçeler olduğu dikkate alınmıştır. Elde edilen sonuçlardan AFAD-RED yazılımı ile yapılan ön hasar tahmininin verdiği beklenen değerlerin (Şekil 8), 1999 yilında gözlenen değerler ile uyumlu olduğu görülmüştür. Bu sonuçlar 1şı̆̆ında çalışmanın bundan sonraki aşamalarında farklı deprem senaryoları için yapılacak deprem risk analizlerinde AFAD-RED yazılımının güvenle kullanılabileceği belirlenmiştir.

Gebze ilçesinin coğrafi konumu göz önüne alındığında S1-S2-S3 fay hattı, S4-S5 fay hatt1 ve S6 fayı farklı büyüklükte depremler oluşturacak şekilde her biri ayrı kırılarak, çeşitli deprem senaryoları elde edilmiştir (Şekil 5). Wells ve Coppersmith (1994) tarafından yapılan çalışmaya göre bir fay için kırılma boyu, kırılma genişliği, kırılma alanı ve yüzey yer değiştirmesine göre ayrı ayrı moment manyitüdünü veren ampirik bağıntılar mevcuttur. Son derece kapsamlı olan bu çalışmadaki formüllerden kırılma boyu için belirlenmiş olanı Denklem (3) senaryo depremleri için kullanılabilir.

$$
M=5.16+1.12 \times \log (S R L)
$$

Burada M moment manyitüdünü, SRL ise fay yüzey kırılma boyunu ifade etmektedir. Bu formülasyon ile S1-S2-S3 fay hattı kırıldığında muhtemel maksimum büyüklüğü $\mathrm{M}_{\mathrm{W}}=7.5$ olan bir deprem meydana getirmesi beklenmektedir. Benzer şekilde S4 ve S5 faylarının birlikte; S6 fayının ise tek başına kırılacağı durum bağımsız olarak hesaplanırsa S4S5 fay hattının maksimum büyüklüğü $\mathrm{M}_{\mathrm{W}}=7.25$, S6 fayının ise maksimum büyüklüğü $\mathrm{M}_{\mathrm{W}}=7.0$ olan deprem üreteceği kabul edilebilir. Her bir fay hattının $\mathrm{M}_{\mathrm{W}}=5$ 'ten başlayarak farklı büyüklükte deprem ürettiği, senaryolarda kabul edilmiştir.

Şekil 9'da AFAD-RED yazılımı ile yapılan deprem risk analizi sonucunda S1-S2-S3 fay hattının kırıldığ1 ve maksimum büyüklüğü $\mathrm{M}_{\mathrm{W}}=7.5$ olan bir deprem meydana geldiğinde zemin etkisi hesaba katılarak Gebze için olası şiddet ve olası hasar durumunu gösteren grafik elde edilmiştir. Şekil 10'da benzer şekilde S1-S2-S3 fay hattının kırılması ve zemin etkisinin dikkate alınmadığı senaryo için olası şiddet ve olası hasar durumunu gösteren grafik elde edilmiştir. Şekil 11'de AFAD-RED yazılımı ile yapılan deprem risk analizi sonucunda S4-S5 fay hattının kırıldığı ve maksimum büyüklüğü $\mathrm{M}_{\mathrm{W}}=7.25$ olan bir deprem meydana geldiğinde zemin etkisinin hesaba katılarak; Gebze için olası şiddet ve olası hasar durumunu gösteren grafik elde edilmiştir. Şekil 12'de yine S4-S5 fay hattının kırıldığı ve zemin etkisinin hesaba katılmadığı senaryosu için olası şiddet ve olası hasar durumunu gösteren grafik çıkarılmıştır. Şekil 13'de AFAD-RED yazılımı ile yapılan deprem risk analizi sonucunda S6 fay hattının kırıldığı ve maksimum büyüklüğü $\mathrm{M}_{\mathrm{W}}=7.0$ olan bir deprem meydana geldiğinde zemin etkisinin hesaba katılması durumunda Gebze için olası şiddet ve olası hasar durumunu gösteren grafik çizilmiştir. Şekil 14 'de ise S6 fay hattının kırıldığında zemin etkisinin hesaba katılmadığ 1 durum için olası şiddet ve olası hasar durumunu gösteren grafik gösterilmiştir. Senaryo depremlerin özellikleri Tablo 1'de verilmiştir. 
Tablo 1: Senaryo depremlerin özellikleri

\begin{tabular}{|l|c|l|l|}
\hline Şekil No & Deprem şiddeti $\left(\mathrm{M}_{\mathrm{W}}\right)$ & İncelenen faylar & Zemin etkisi dahil edilmiş mi? \\
\hline Şekil 9 & 7.5 & S1-S2-S3 & Evet \\
\hline Şekil 10 & 7.5 & S1-S2-S3 & Hayır \\
\hline Şekil 11 & 7.25 & S4-S5 & Evet \\
\hline Şekil 12 & 7.25 & S4-S5 & Hayır \\
\hline Şekil 13 & 7.0 & S6 & Evet \\
\hline Şekil 14 & 7.0 & S6 & Hayır \\
\hline
\end{tabular}

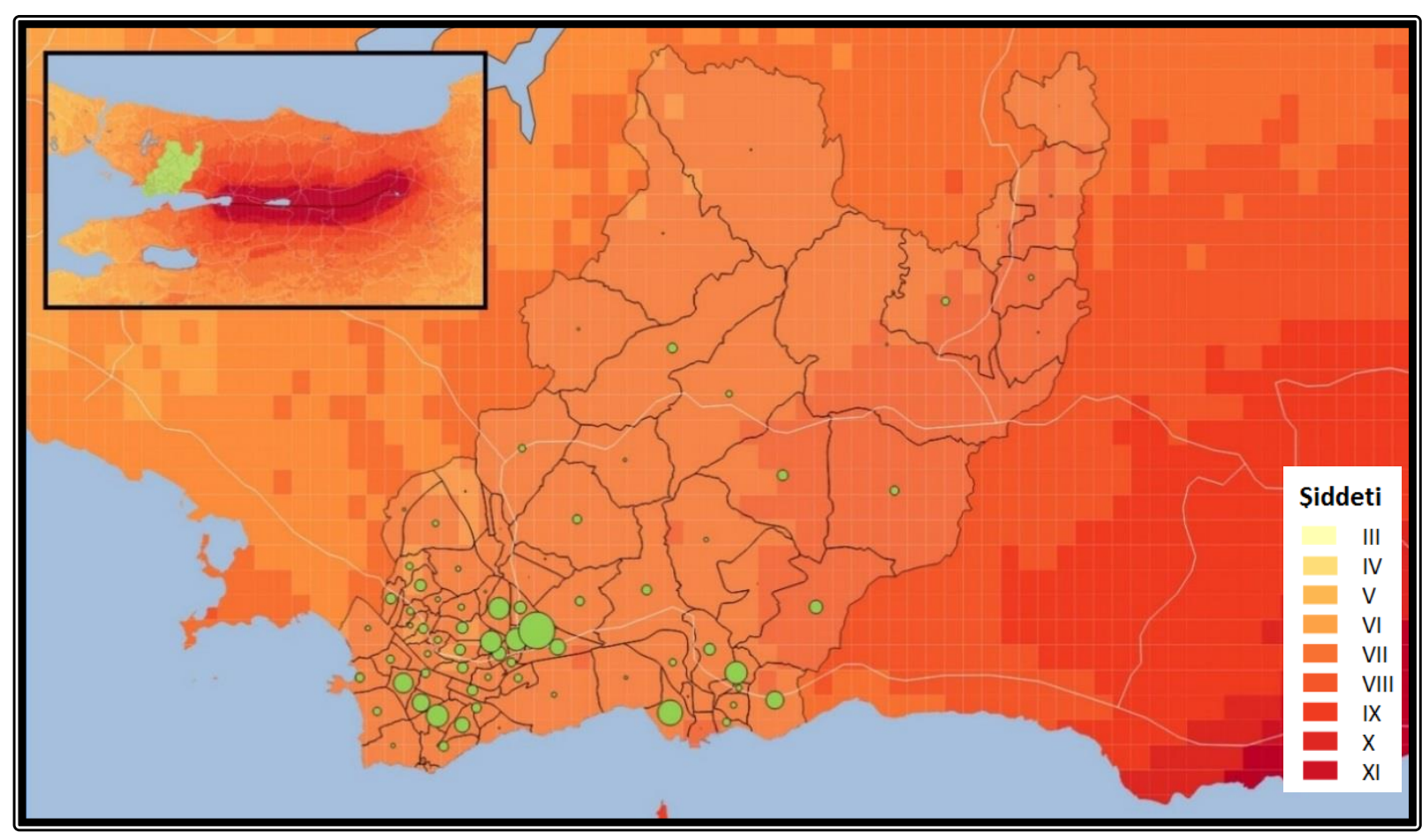

Şekil 8: 1999 yılı Kocaeli Depremi şiddet ve olası hasar durumu grafiği.

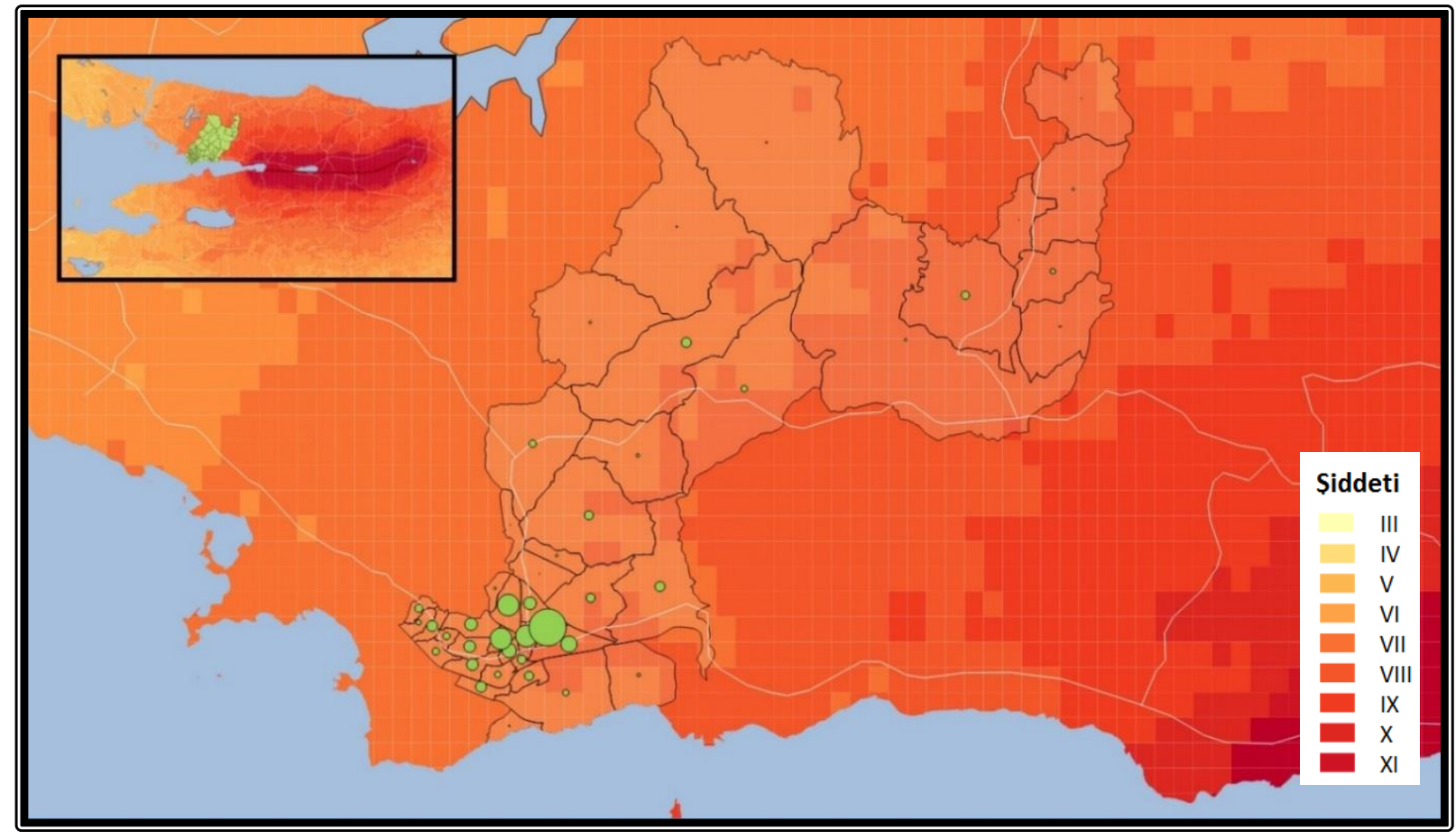

Şekil 9 S1-S2-S3 Fay Hattı, $M_{W}=7.5$ için zemin etkisinin hesaba katılması durumu 


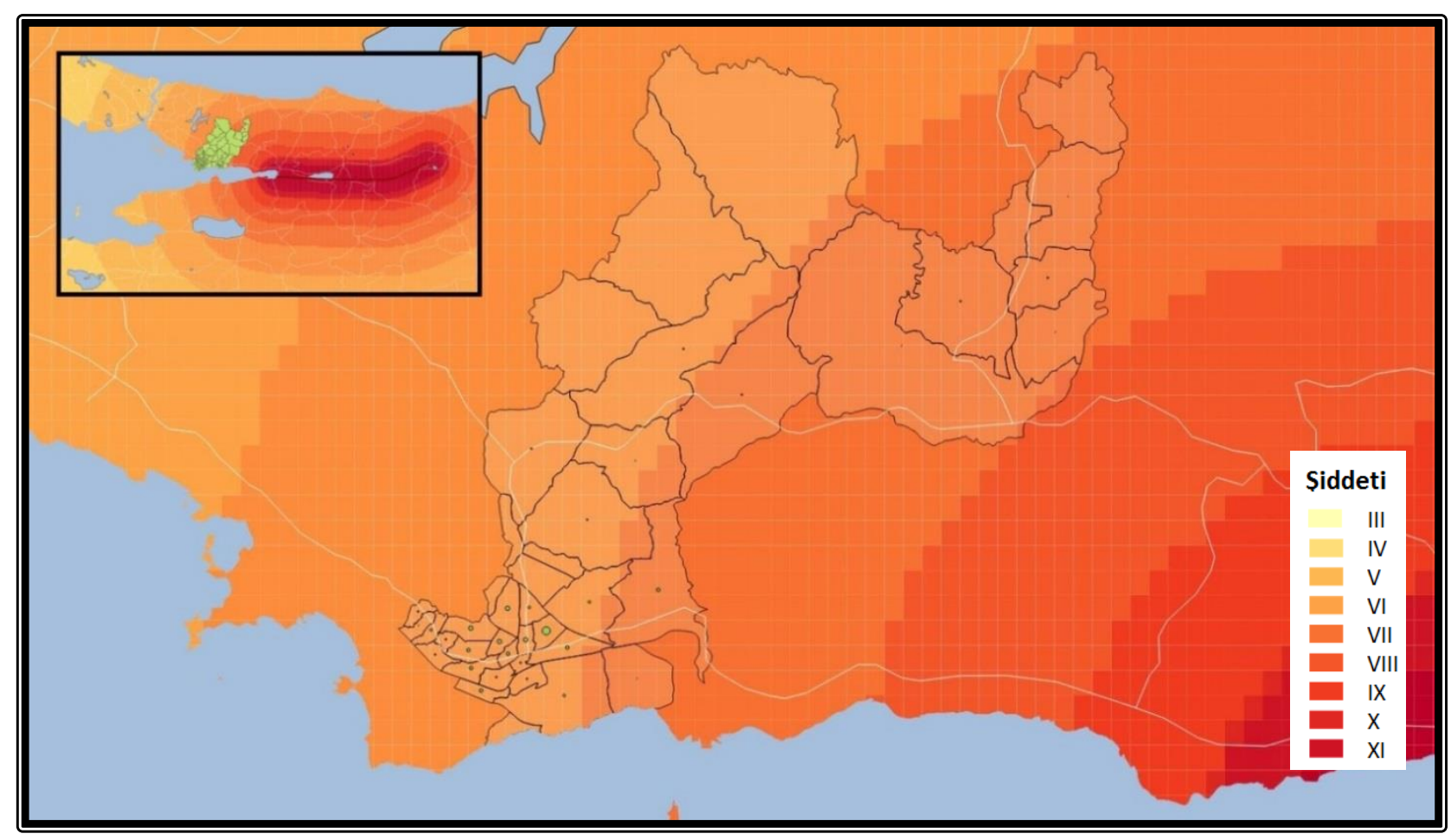

Şekil 10: S1-S2-S3 Fay hattı, $M_{W}=7.5$ için zemin etkisinin hesaba katılmaması durumu

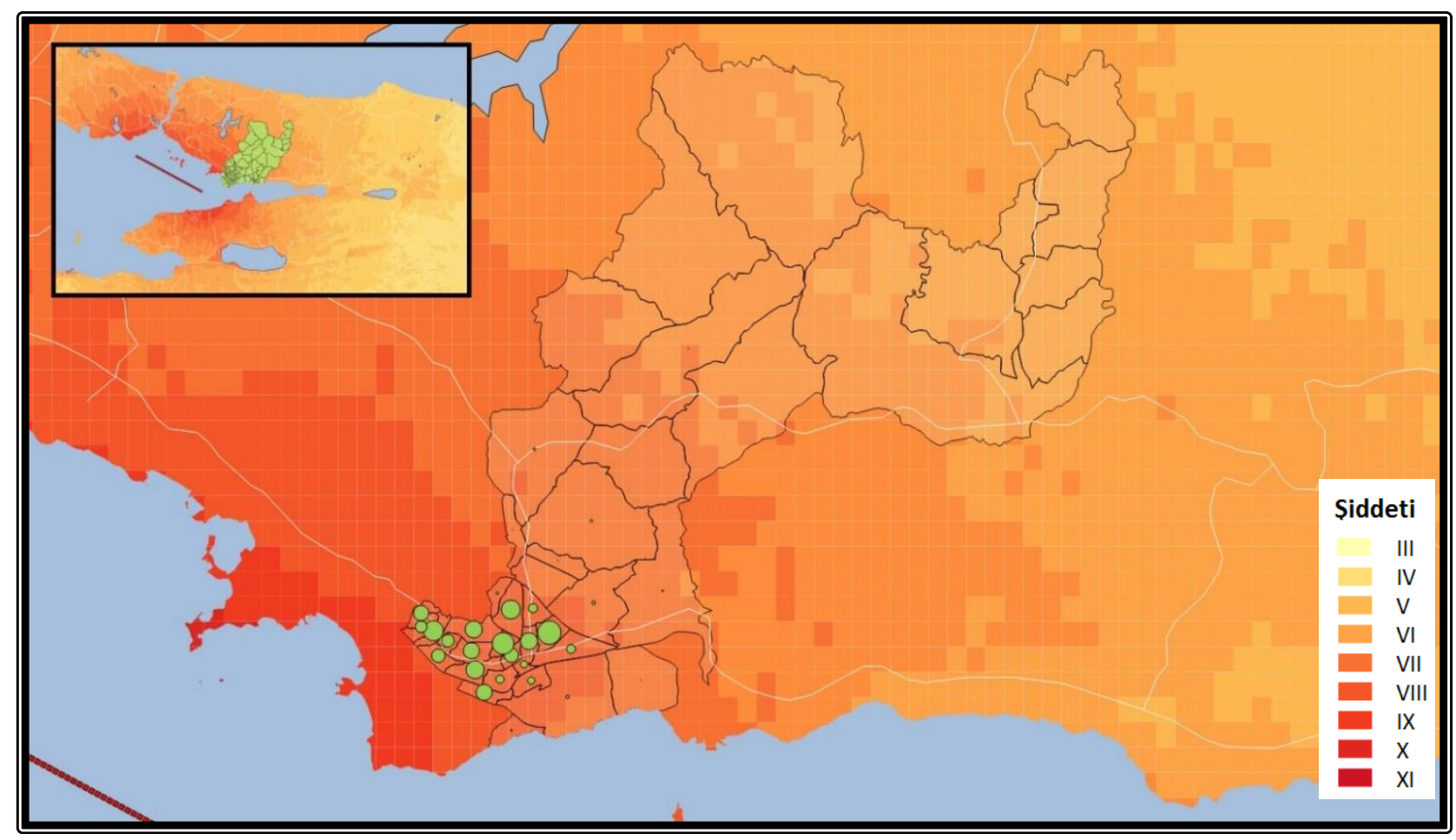

Şekil 11: S4-S5 Fay Hattı, $M_{W}=7.25$ için zemin etkisinin hesaba katılması durumu 


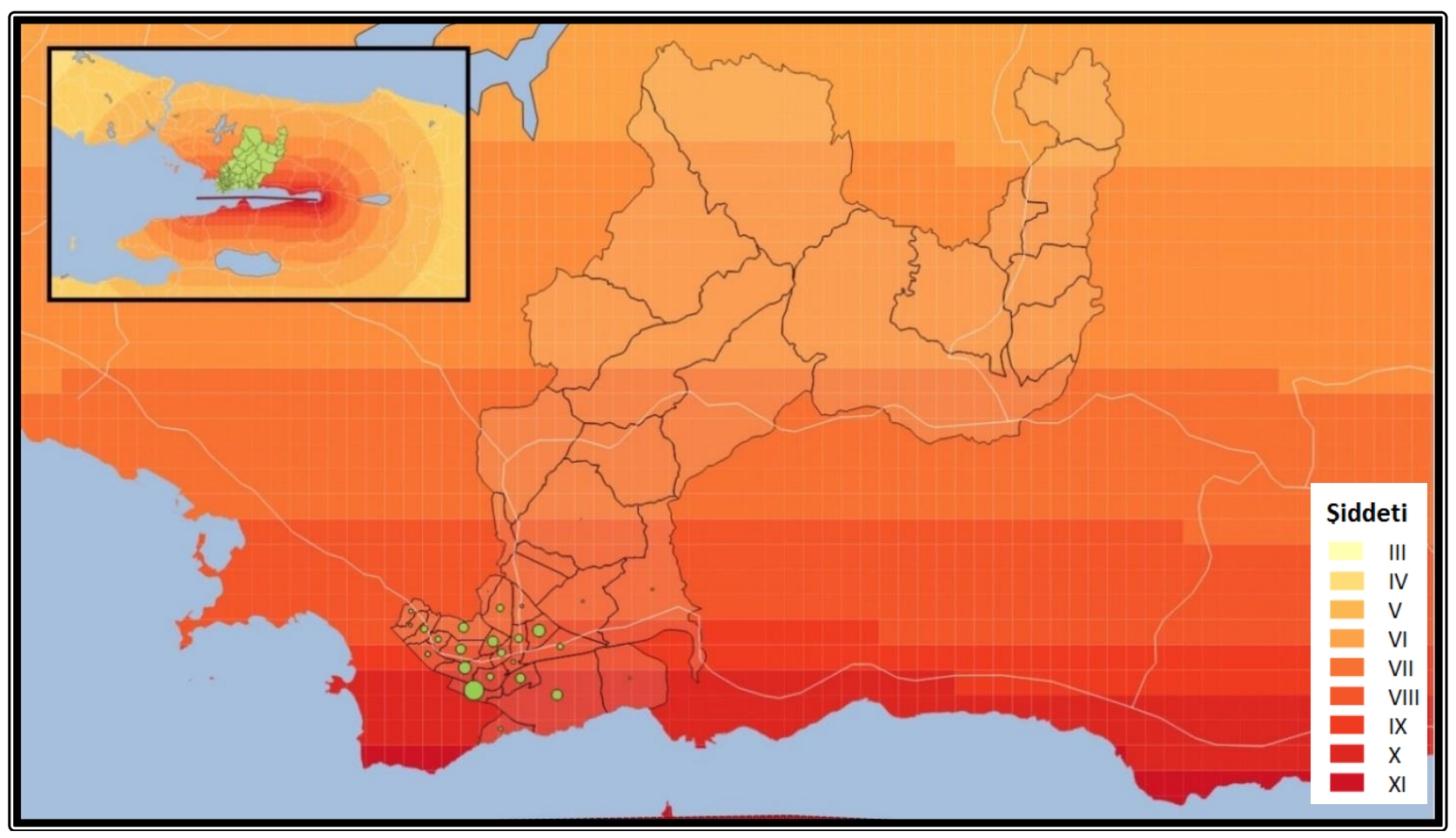

Şekil 12: S4-S5 Fay Hattı, $M_{W}=7.25$ için zemin etkisinin hesaba katılmaması durumu

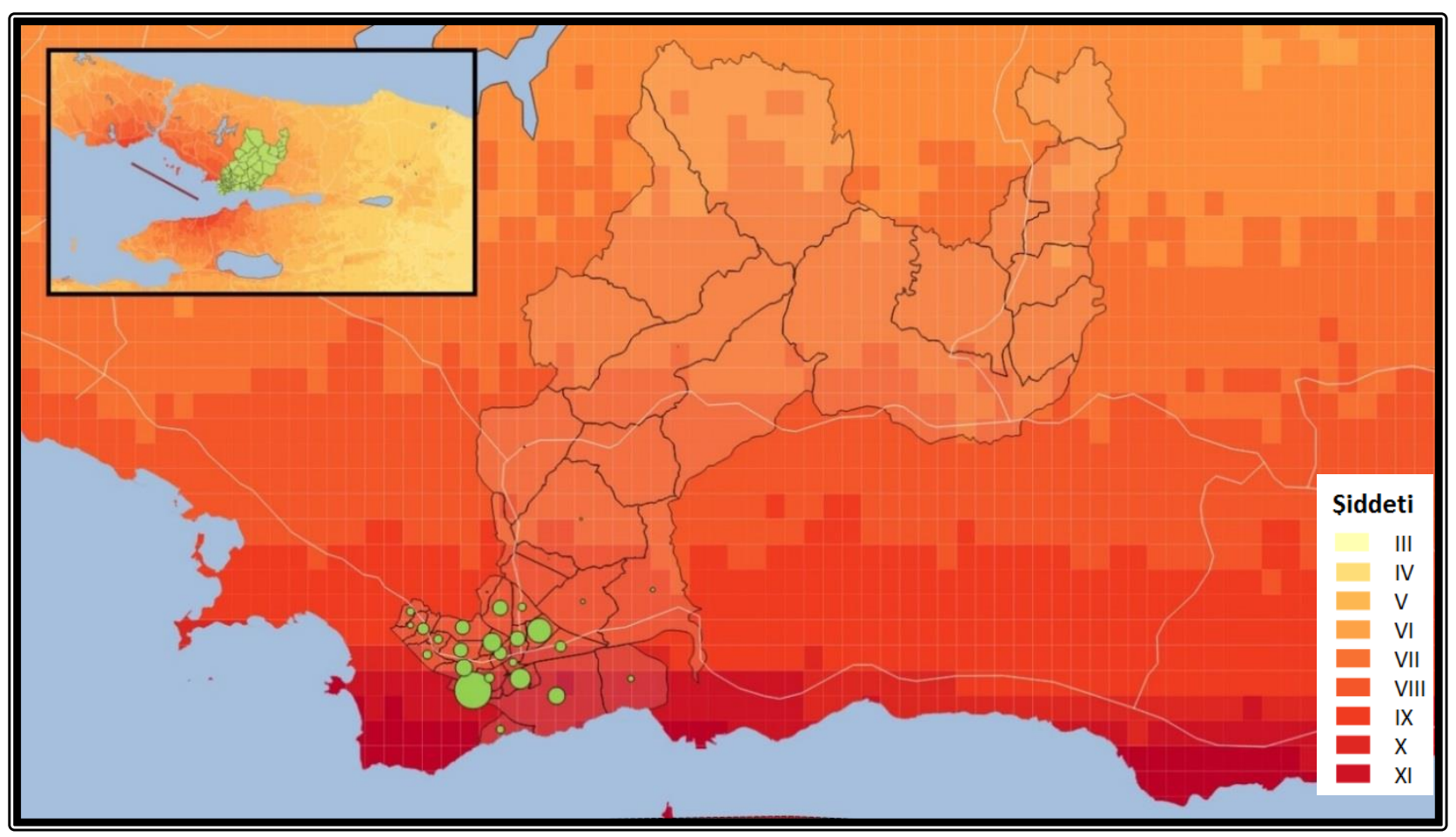

Şekil 13: S6 Fay Hattı, $M_{W}=7.0$ Için zemin etkisinin hesaba katılması durumu 


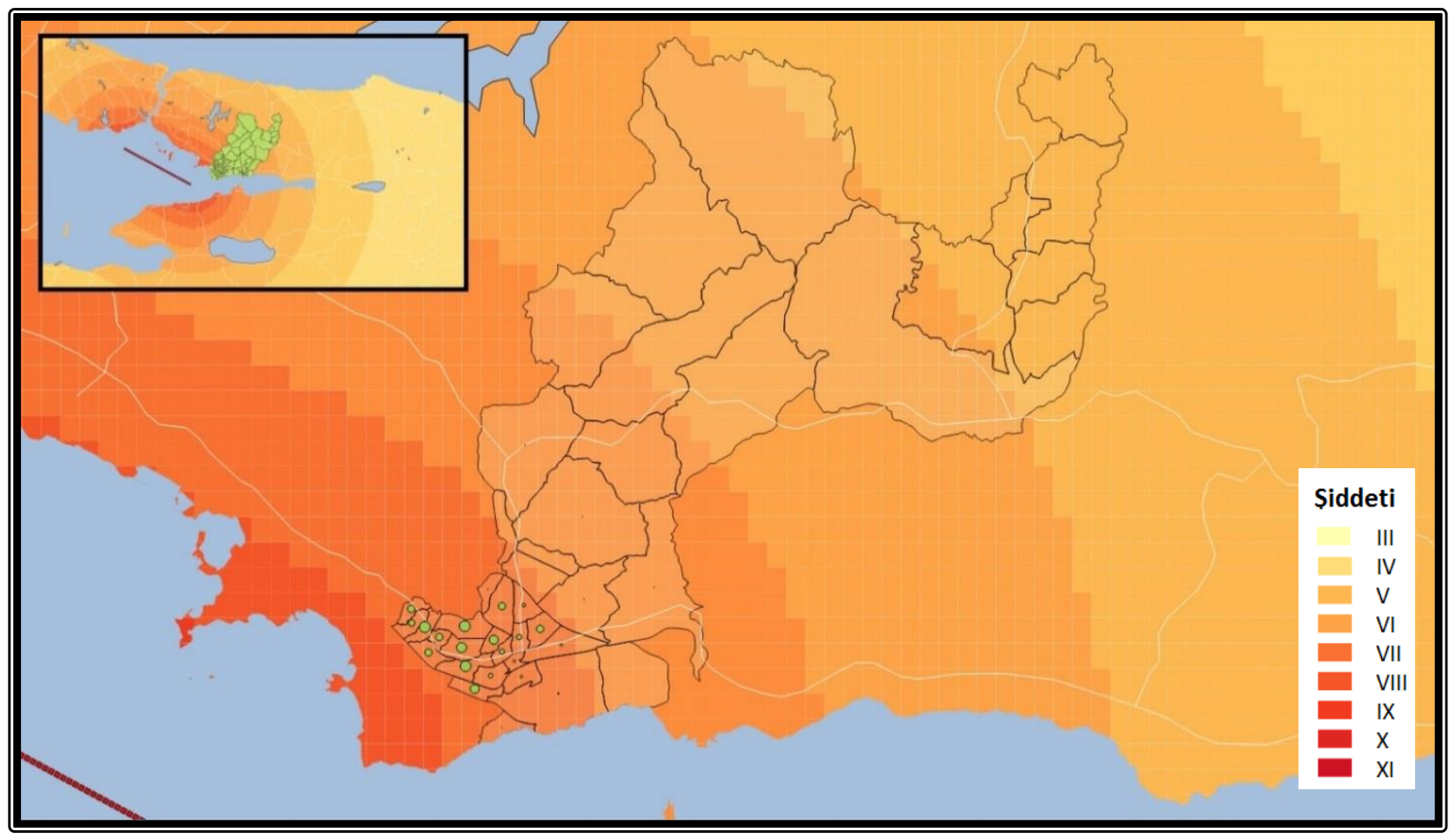

Şekil 14: S6 Fay Hattı, $M_{W}=7.0$ için zemin etkisinin hesaba katılmaması durumu

Şekil 15-Şekil 29 arasında AFAD-RED yazılımı ile yapılan deprem risk analizi sonucunda S1-S2-S3, S4-S5 ve S6 fay hatlarının ayrı ayrı kırılması durumunda oluşan farklı büyüklükteki deprem senaryoları ve zemin etkisinin dikkate alınıp alınmaması durumları için ayrı ayrı, olası hasar gören bina sayısı, can kaybı ve barınak ihtiyacı olan insan oranları verilmiştir.

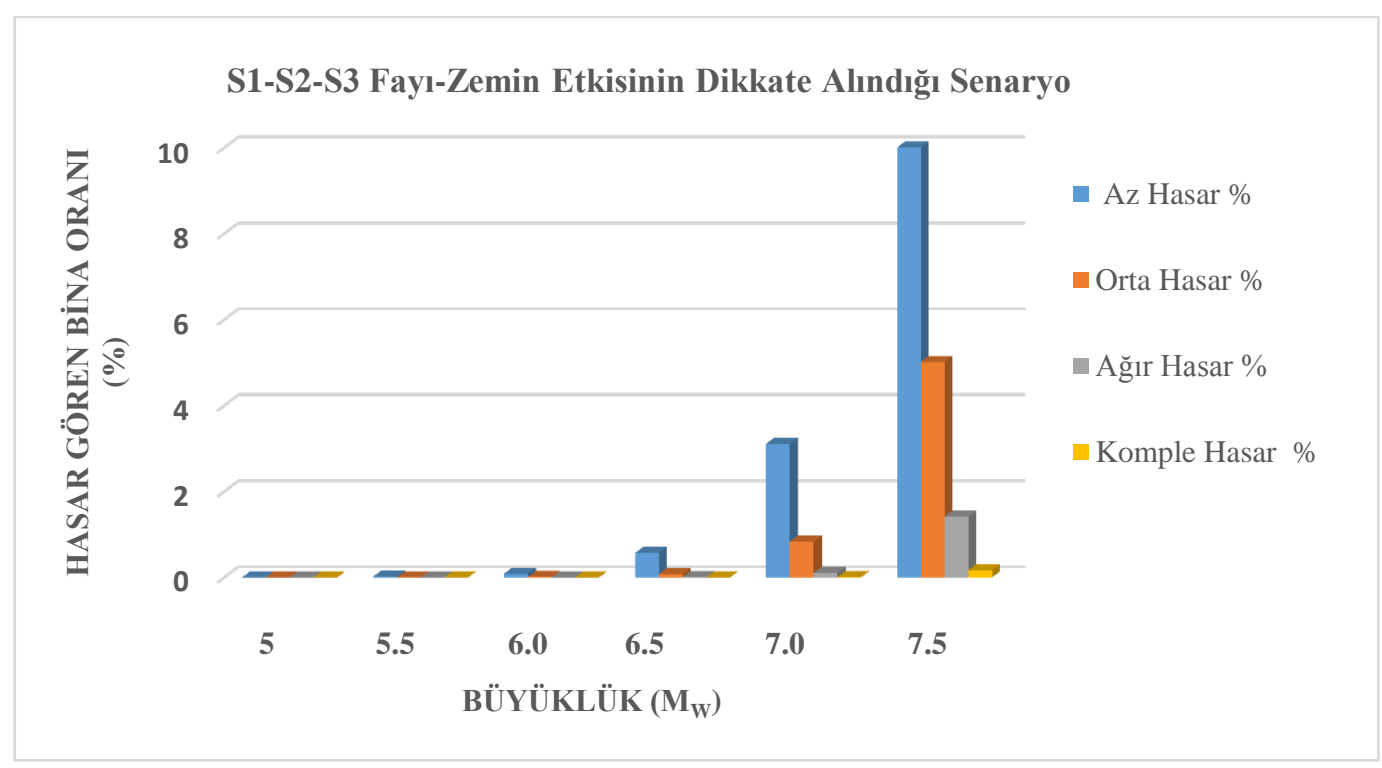

Şekil 15: S1-S2-S3 Fay Hattı, zemin etkisinin hesaba katılması durumu için hasar gören bina oranı (\%) 


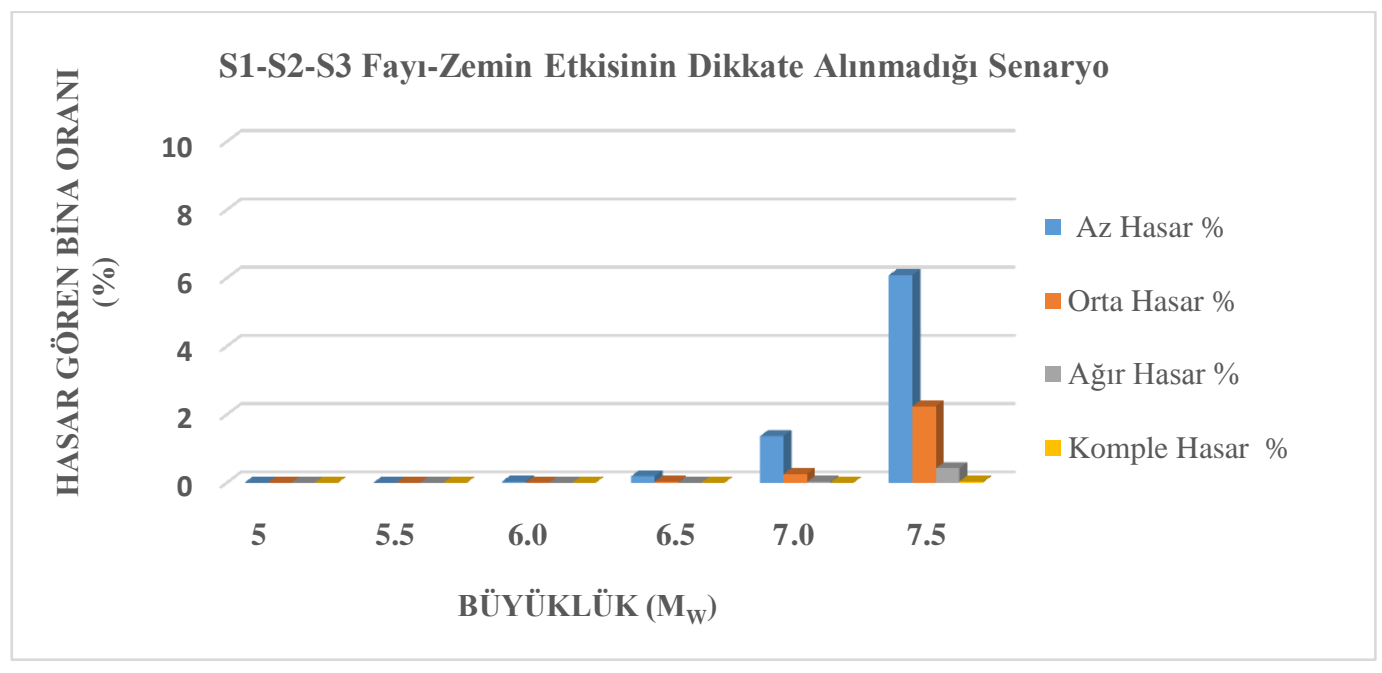

Şekil 16: S1-S2-S3 Fay Hattı, zemin etkisinin hesaba katılmaması durumu için hasar gören bina oranı (\%)

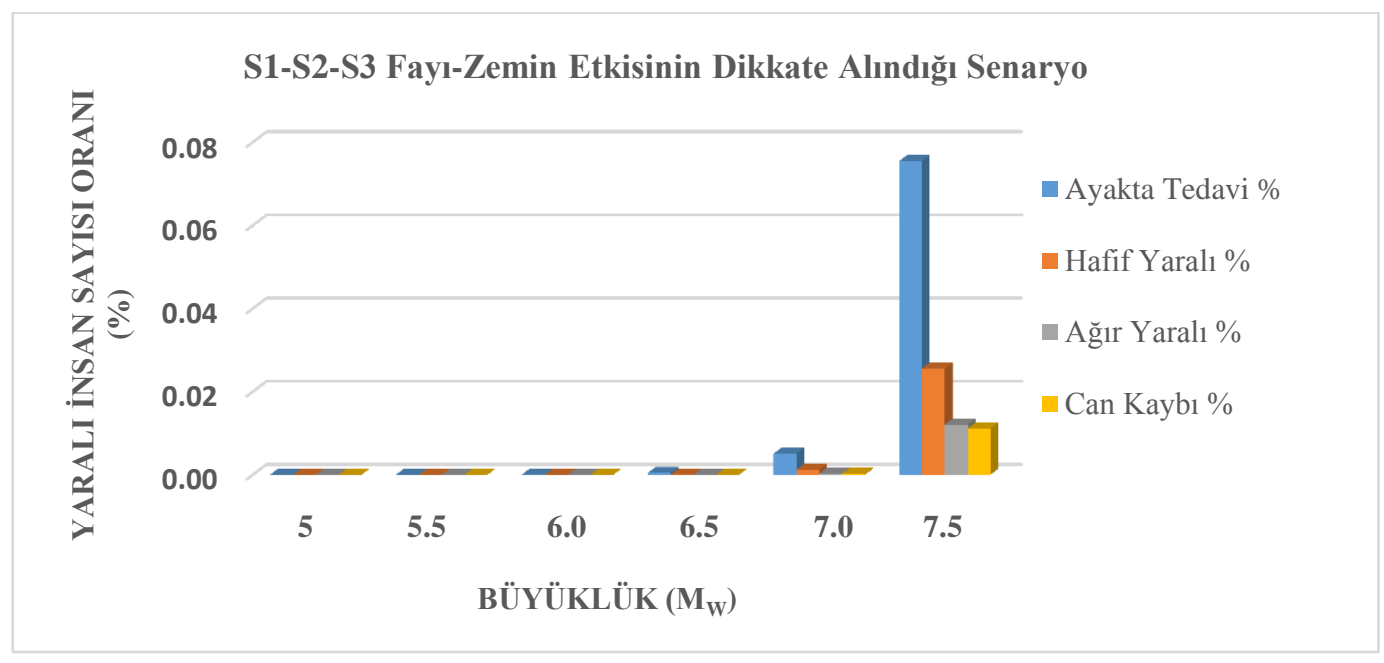

Şekil 17: S1-S2-S3 Fay Hattı, zemin etkisinin hesaba katılması durumu için yaralı insan sayısı oranı (\%)

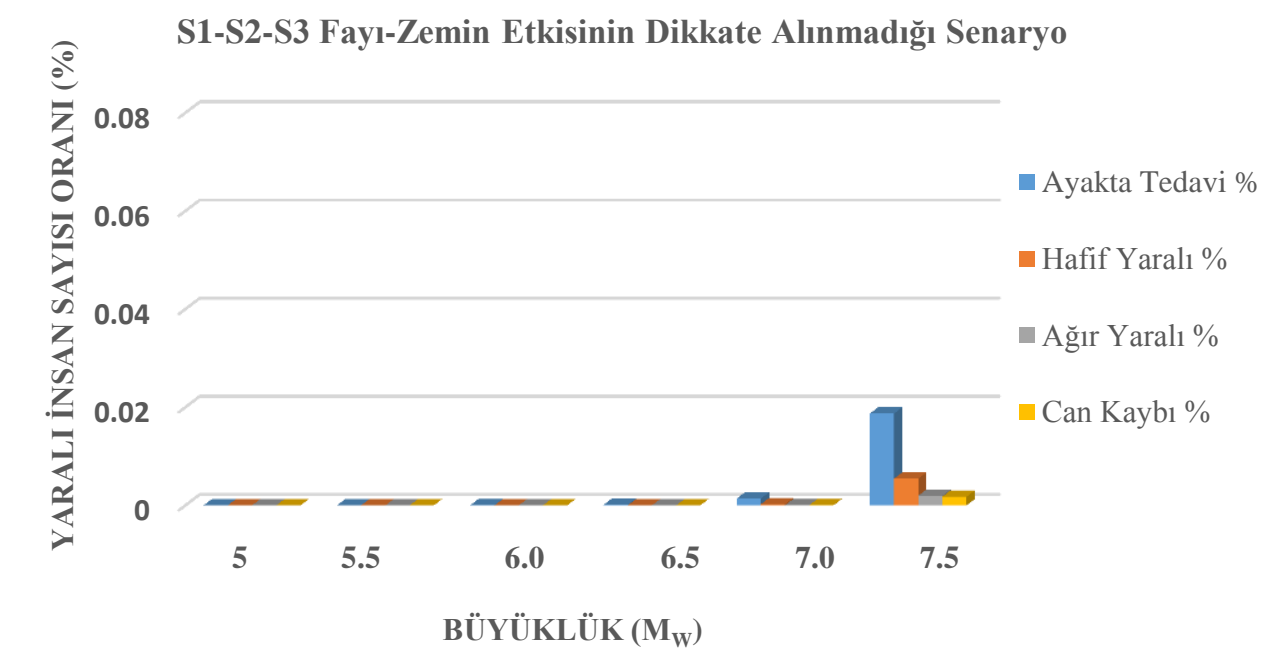

Şekil 18: S1-S2-S3 Fay Hattı, zemin etkisinin hesaba katılmaması durumu için yaralı insan sayısı oranı (\%) 


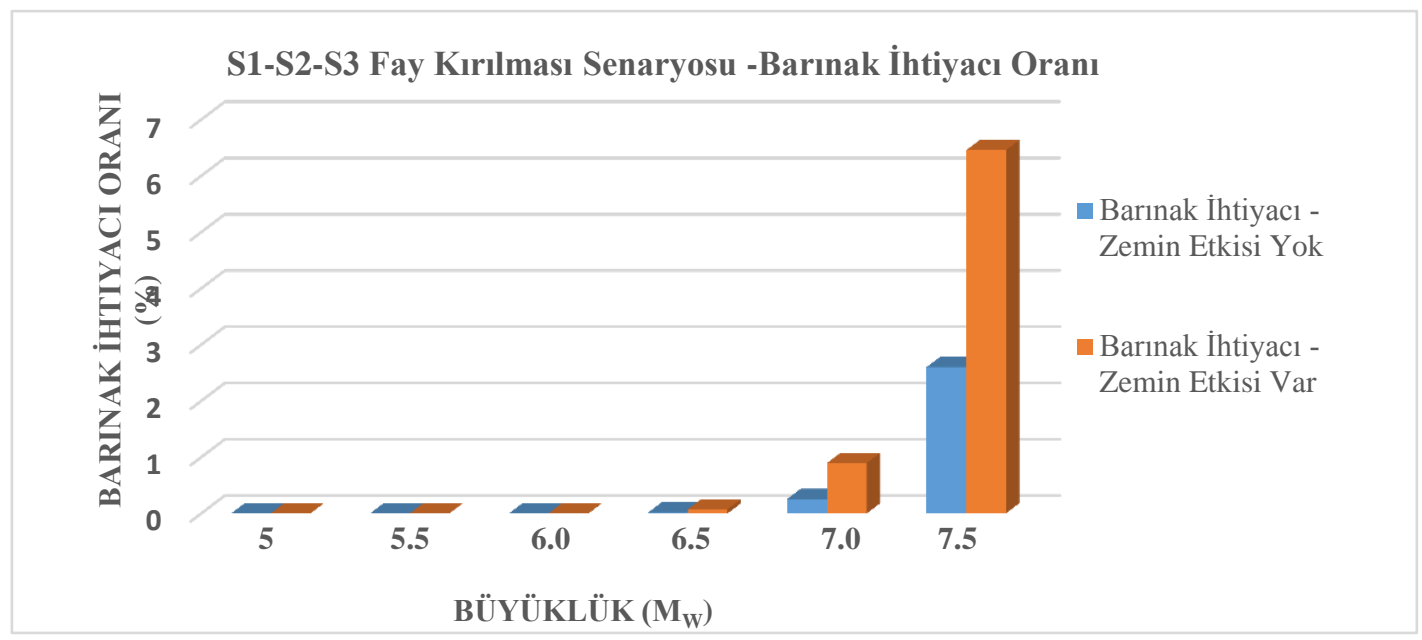

Şekil 19: S1-S2-S3 Fay Hattı, zemin etkisinin hesaba katılması ve katılmaması durumları için barınak ihtiyacı oranı (\%)

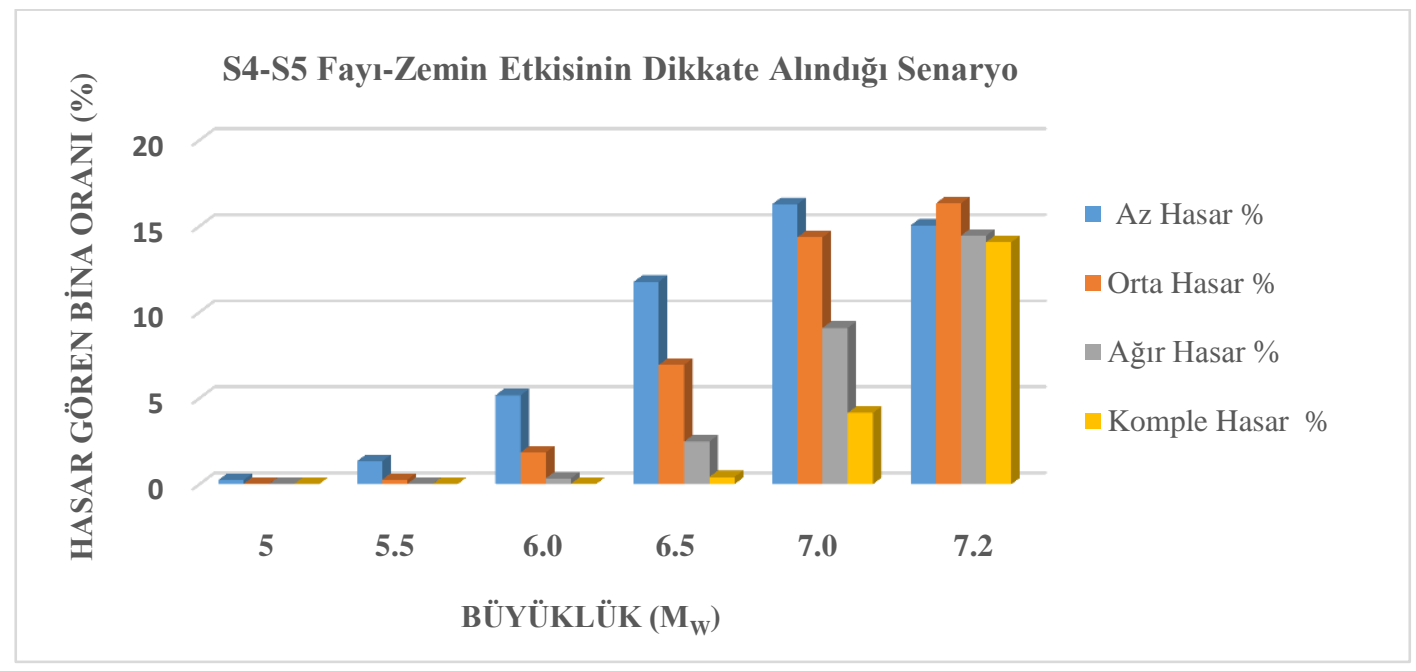

Şekil 20: S4-S5 Fay Hattı, zemin etkisinin hesaba katılması durumu için hasar gören bina oranı (\%)

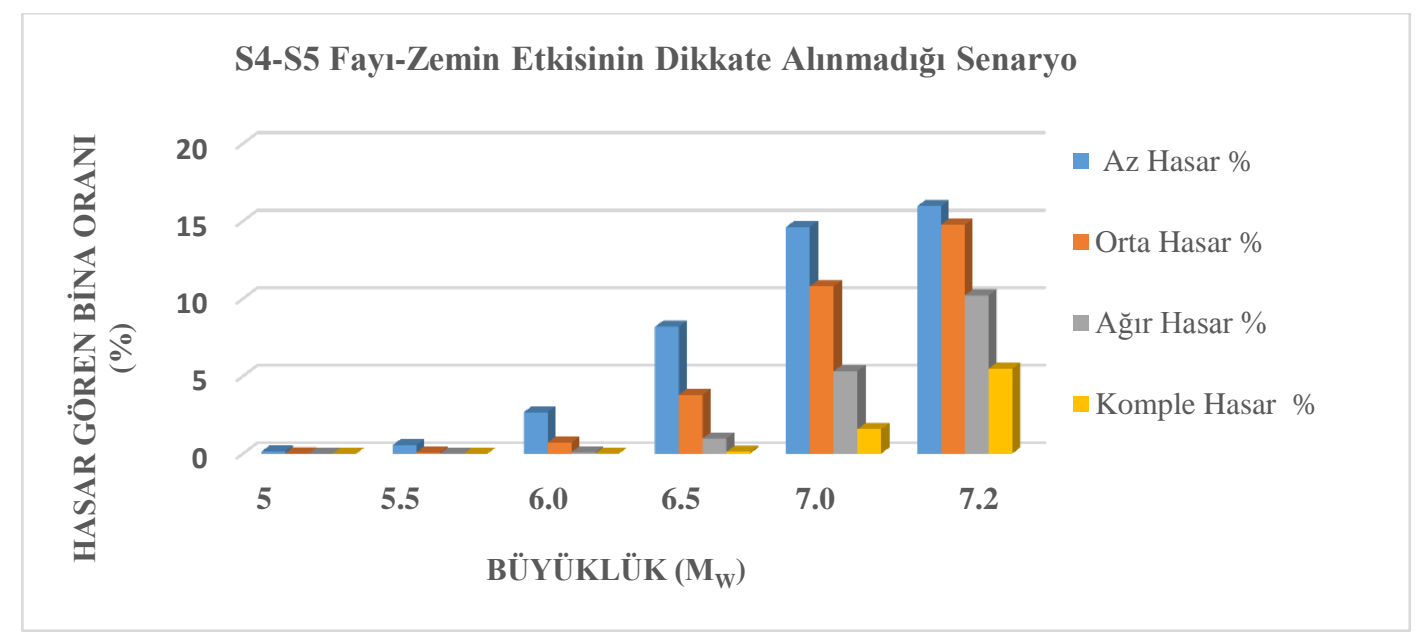

Şekil 21: S4-S5 Fay Hattı, zemin etkisinin hesaba katılmaması durumu için hasar gören bina oranı (\%) 


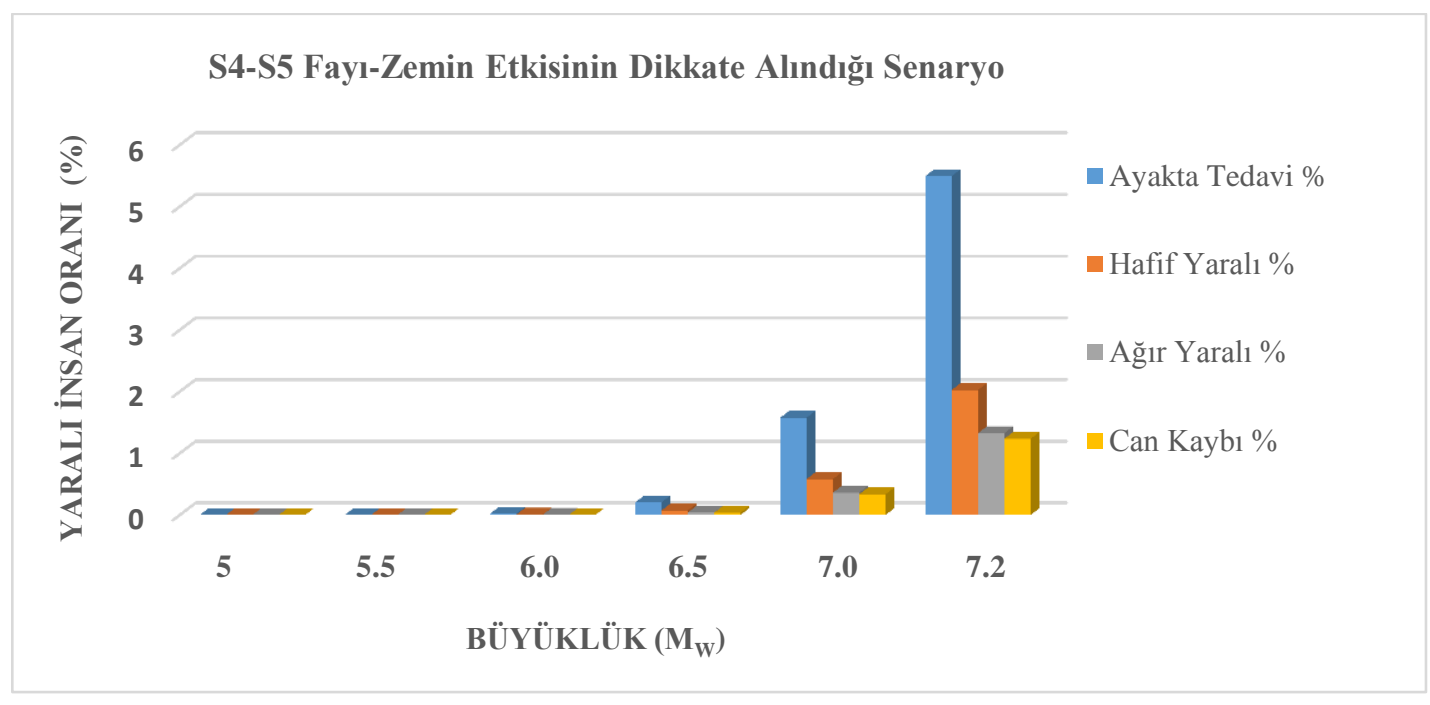

Şekil 22: S4-S5 Fay Hattı, zemin etkisinin hesaba katılması durumu için yaralı insan sayısı oranı (\%)

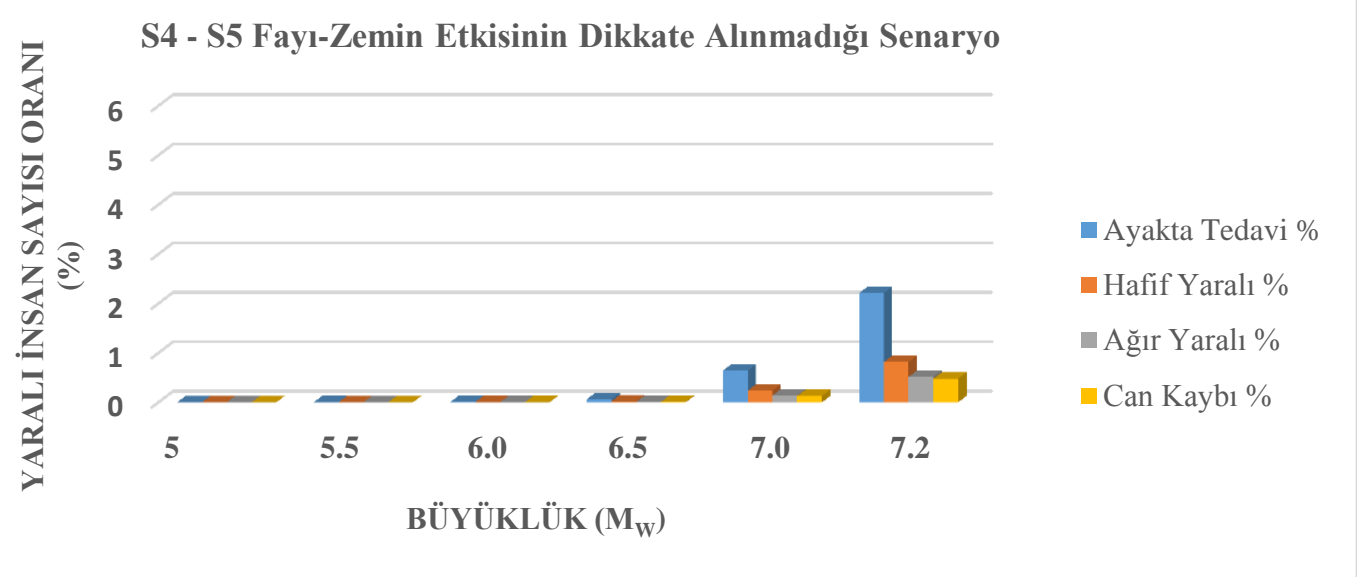

Şekil 23: S4-S5 Fay Hattı, zemin etkisinin hesaba katılmaması durumu için yaralı insan sayısı oranı (\%)

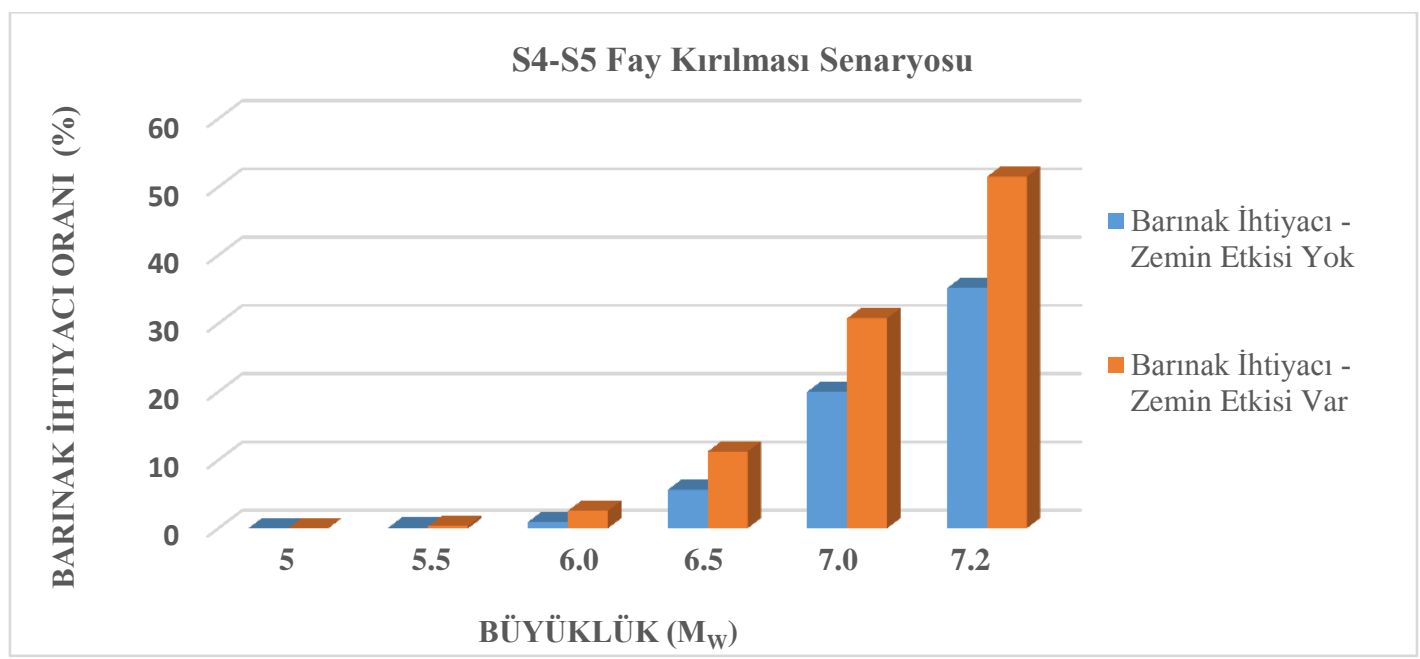

Şekil 24: S4-S5 Fay Hattı, zemin etkisinin hesaba katılması ve katılmaması durumları için barınak ihtiyacı oranı (\%) 


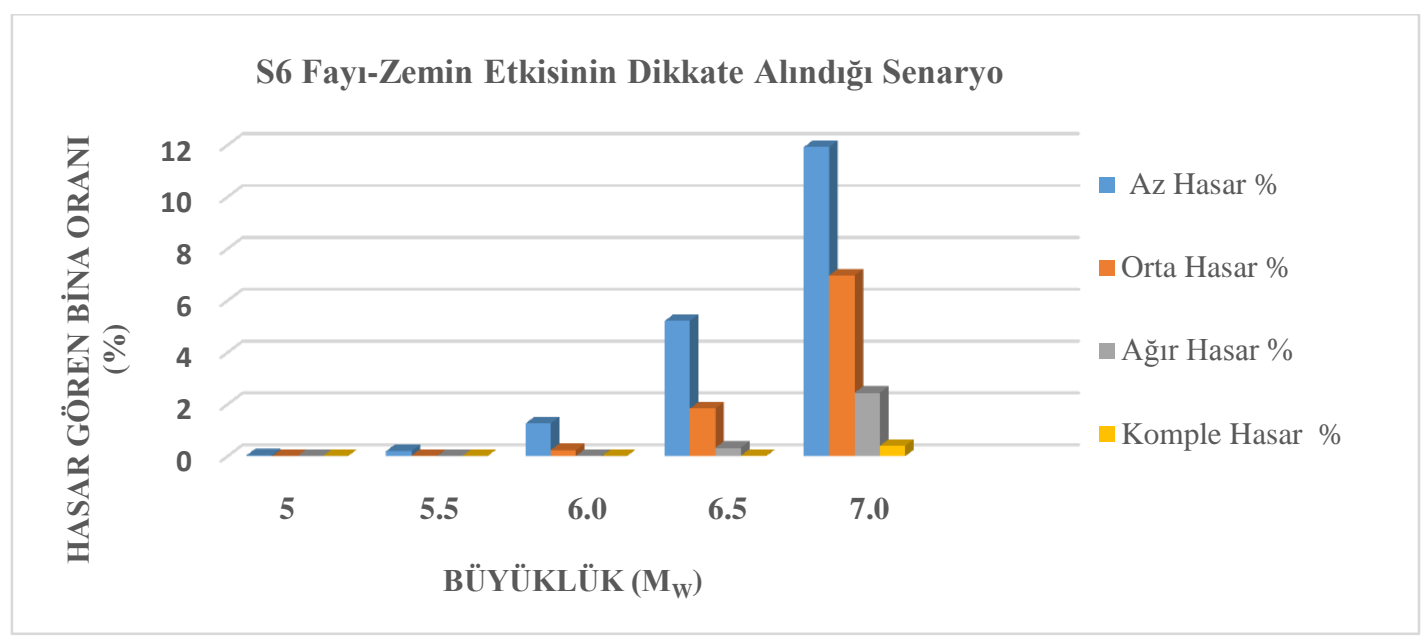

Şekil 25: S6 Fay Hattı, zemin etkisinin hesaba katılması durumu için hasar gören bina oranı (\%)

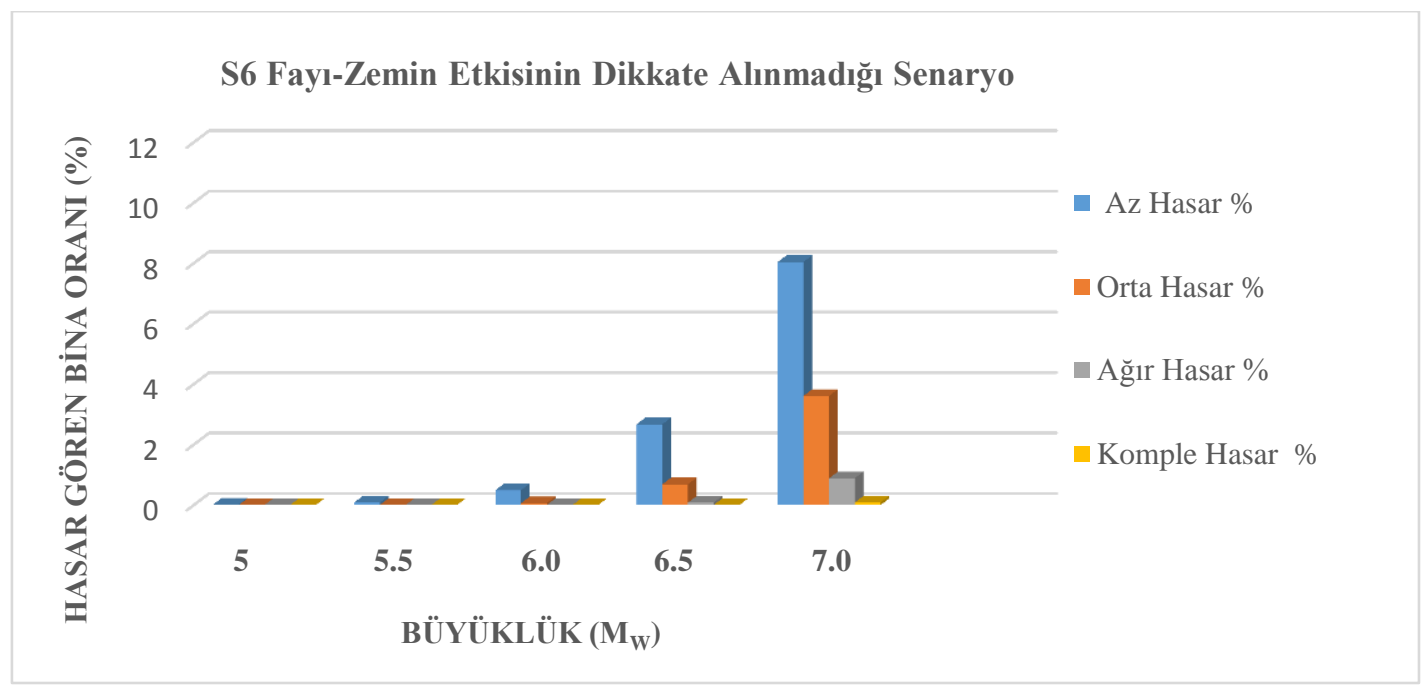

Şekil 26: S6 Fay Hattı, zemin etkisinin hesaba katılması durumu için hasar gören bina oranı (\%)

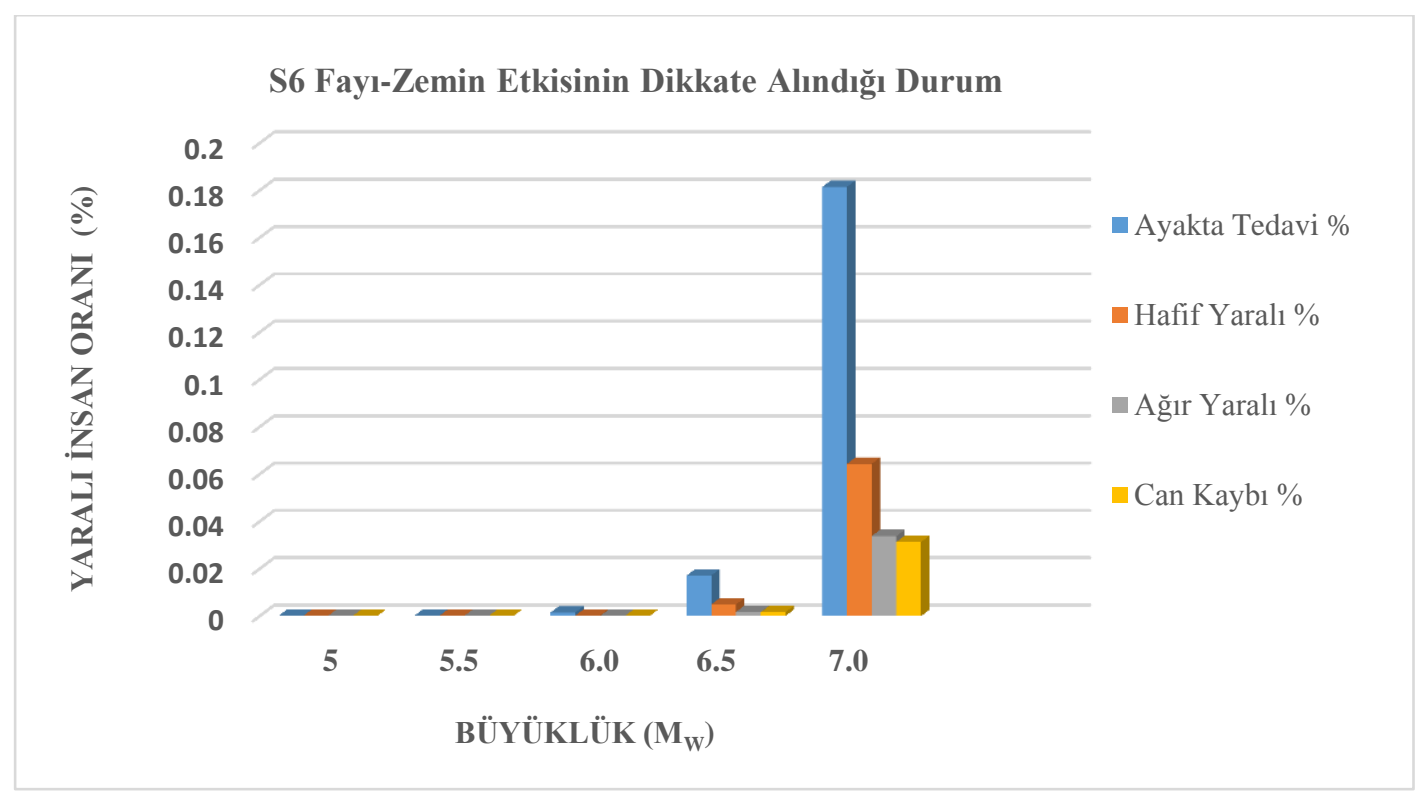

Şekil 27: S6 Fay Hattı, zemin etkisinin hesaba katılması durumu için yaralı insan sayısı oranı (\%) 


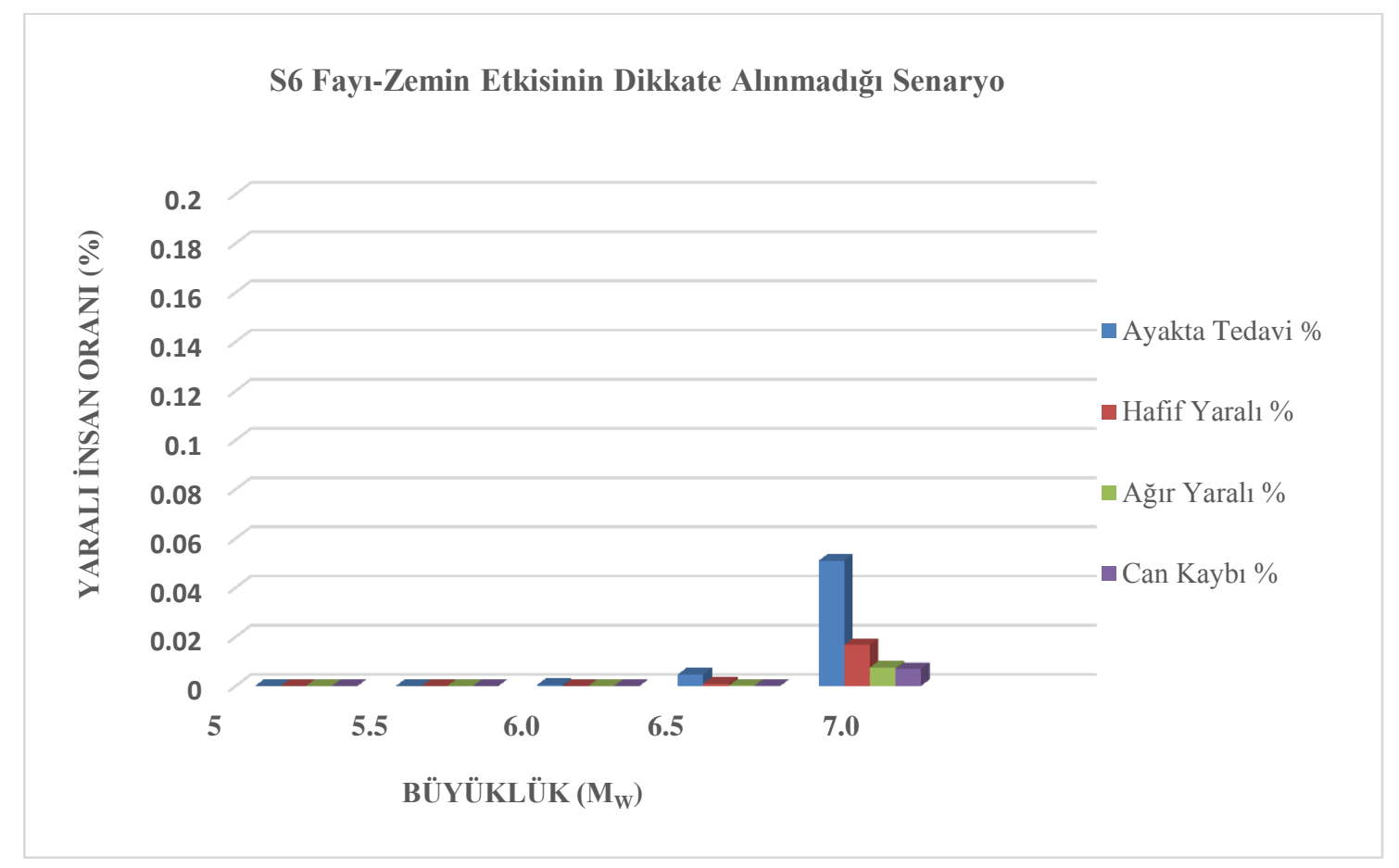

Şekil 28: S6 Fay Hattı, zemin etkisinin hesaba katılmaması durumu için yaralı insan sayısı oranı (\%)

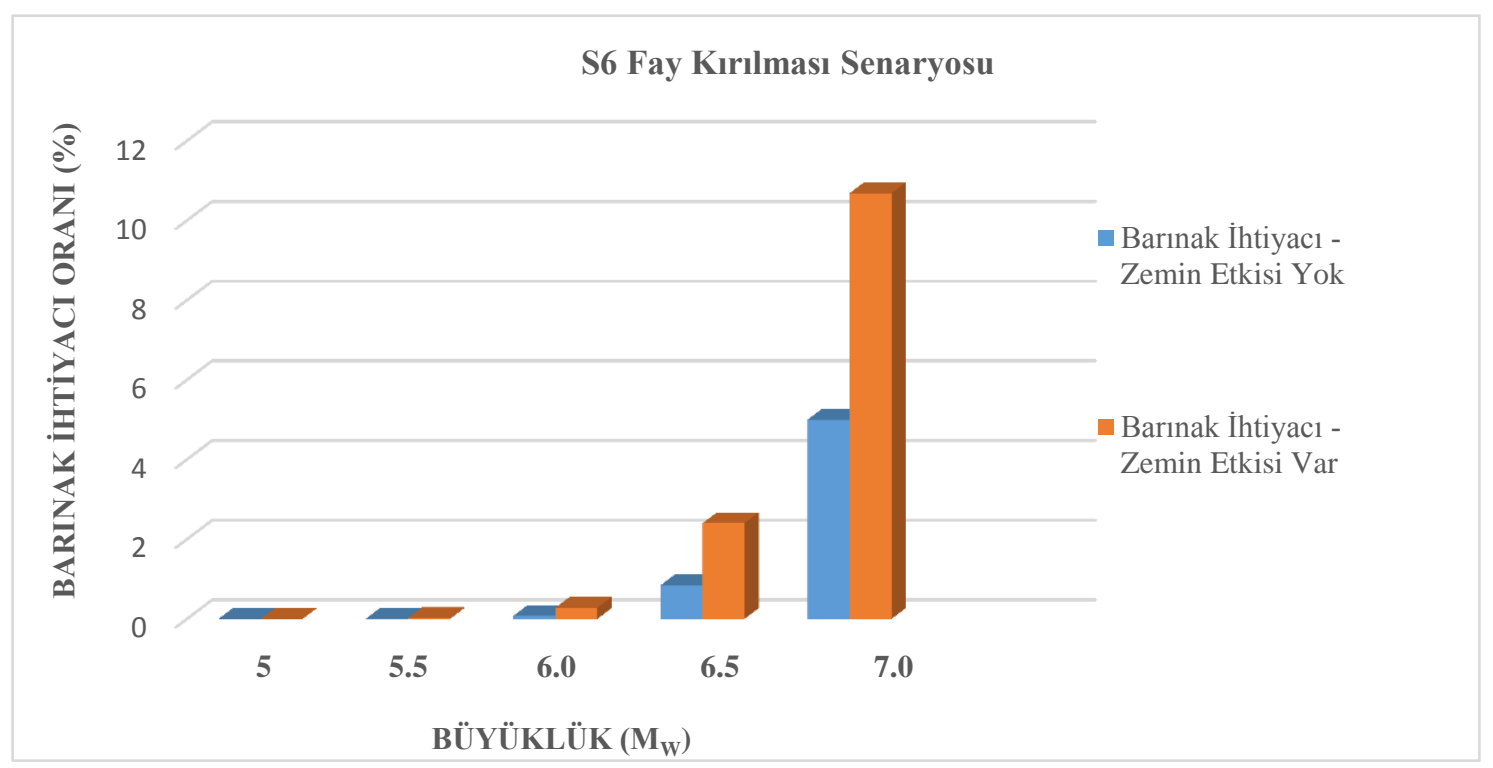

Şekil 29: S6 Fay Hattı, zemin etkisinin hesaba katılması ve katılmaması durumları için barınak ihtiyacı oranı(\%)

\section{Tartışma ve Sonuçlar}

Ülkemizde jeolojik özellikler, yer-iklim koşulları ve topoğrafik yapı sebebiyle birçok doğal afet meydana gelmektedir. Doğal afetler can kaybına, fiziksel kayıplara ve zamana göre değişen boyutta ekonomik zararlara neden olmaktadır. Etkin bir afet yönetimi ile ülkemizin uğrayabileceği zararlar azaltılabilecektir. Ancak, afet yönetimi bileşenleri genellikle belirsizlik içermektedir.

Dünyada ve ülkemizde neden olduğu can ve mal kayıplarının büyüklüğü nedeniyle, deprem felaketi; öncelikle önlem alınması gerekli doğal bir afettir. Deprem tehlikesi; depremin oluş yeri ve zamanı, büyüklüğü, mekanizması gibi birçok belirsizlik taşımaktadır. Yapılan deprem riski hesaplamalarında; deprem bölgesindeki yapıların kalitesindeki belirsizlikler, risk analizinde kullanılan yöntemlerde yapılan kabuller ve zemin etkisinin dikkate alınıp alınmaması gibi faktörler aynı anda değerlendirilmektedir. 
Yapılan bu çalışma kapsamında, deprem riski belirsizliklerinin afet yönetimindeki etkileri değerlendirilmiş, seçilen alanda depreme ait belirsizliklerden deprem büyüklüğü ve zemin etkisinin hesaba katılıp katılmadığı durumlar incelenmiştir. Çalışma, aktif bir fay hattında bulunan ve sahip olduğu birçok organize sanayi bölgesi ile ülkemiz sanayisi için önemli bir yere sahip olan Gebze ilçesi için yapılmış; ilk olarak kırılması muhtemel üç fay hattı seçilmiş, daha sonra seçilen bu fay hatlarının ayrı ayrı farklı büyüklükte deprem oluşturacak şekilde kırıldığı kabul edilerek senaryo depremler elde edilmiştir. Senaryo depremlerle, kırılması olası her bir fay hattı için deprem şiddet eğrileri, olası kayıp ve hasar oranları çıkarılmıştır. Yapılan deprem risk analizleri sonucunda, Gebze ilçesinde olası can ve mal kaybının yüksekliği; yerleşmelerde deprem afetini dikkate alan bir planlama yapılmasının gerekliliğini ortaya koymaktadır. Bu hesaplamalarda zemin etkisi de dikkate alındığında bölgede depremden en fazla kıyı şeridinin ve bina kalitesinin yeterince iyi olmadığı bilinen kırsal alanların etkilenerek, yapılarda hasar oluşabileceği bulunmuş; bu nedenle kentsel dönüşümün ivedilikle başlatılması gerekli olduğu görülmüştür. Analizlerde 1-4 katlı betonarme yapılar için hesaplanmış olan yapısal hasargörebilirlik oranları dikkate alınarak elde edilen sonuçlar sayısal olarak incelendiğinde, 1999 Kocaeli depremine eşdeğer büyüklükte bir deprem senaryosu için mevcut binaların \%1,5 ağır hasarlı, \%5 orta hasarlı olacağı öngörülmektedir. Bu nedenle söz konusu yüksek hasarların oluşmasına neden olacak en büyük etkenin zemin olduğu, bu çalışmayla gösterilmiştir.

Bölgedeki fay hatları, olası deprem büyüklükleri, bina kalitesi gibi belirsizlikler ve zemin etkisi dikkate alınarak yapılan olası deprem senaryolarından çıkan sonuçlara göre; Gebze'ye ek olarak, Darıca, Çayırova, Dilovası yerleşimlerinde de deprem ön hasar çalışmaları yapılmalı ve afet sonrası karşılaşılabilecek hasarların azaltılması için gerekli önlemler alınmalıdır. Gebze ilçesinin ülke sanayisi bakımından önemi dikkate alındığında, mevcut sanayi bölgeleri için mikro-bölgeleme yöntemiyle risk değerlendirmelerine göre gerekli tedbirlerin alınması, oluşabilecek felaketlerin etkisini azaltmak için önemli bir husus olarak görülmektedir.

\section{Teşekkür}

Bu çalışma, T.C. Başbakanlık Afet ve Acil Durum Yönetimi Başkanlığı-Ulusal Deprem Araştırma Programı (UDAP) kapsamında ve UDAP-G-14-11 nolu proje ile desteklenmiştir.

\section{Kaynaklar}

Abrahamson N., Silva W.J., (1997), Empirical response spectral attenuation relations for shallow crustal earthquakes, Seismological Research Letters, 68, 94-127.

Akıncıtürk N., (2003), Yapı Tasarımında Mimarın Deprem Bilinci, Uludağ Üniversitesi Mühendislik-Mimarlık Fakültesi Dergisi, 8, 189-201.

Ambraseys N.N., Simpson K.U., Bommer J.J., (1996), Prediction of horizontal response spectra in Europe, Earthquake Engineering \& Structural Dynamics, 25, 371-400.

Balamir M., (2000), Türkiye Yeni Bir Deprem Stratejisi mi Geliştiriyor?, Mimarlık Dergisi, 295, 44-47.

Balamir M., (2004), Deprem Konusunda Güncel Gelişmeler ve Beklentiler, Planlama: TMMOB Şehir Plancıları Odası Yayını, 27, $15-28$.

Balyemez S., Berköz L., (2005), Hasar görebilirlik ve kentsel deprem davranışı, İTÜ Dergisi, 4, 3-14.

Boore D.M., Joyner W.B., Fumal T.E., (1997), Equations for estimating horizontal response spectra and peak acceleration from western North American earthquakes: a summary of recent work, Seismological Research Letters, 68, 128-153.

Çavuş U.Ş., Akyol C., (2015), Burdur Deprem Riski ve Hasar Tahmini, Uluslararası Burdur Deprem ve Çevre Sempozyumu, Mehmet Akif Ersoy Üniversitesi, Burdur.

Douglas J., (2003), Earthquake ground motion estimation using strong-motion records: a review of equations for the estimation of peak ground acceleration and response spectral ordinates, Earth-Science Reviews, 61, 43-104.

Erdik M., Demircioglu M., Sesetyan K., Durukal E., Siyahi B., (2004), Earthquake hazard in Marmara region, Turkey, Soil Dynamics and Earthquake Engineering, 24, 605-631.

Erdik M., Fahjan Y., Özel O., Alcik H., Mert A., Gul M., (2003), Istanbul earthquake rapid response and the early warning system, Bulletin of Earthquake Engineering, 1, 157-163.

Eren C., (2014), Tek Katlı Betonarme Sanayi Yapıları İçin Hızlı Hasar Hesaplama Yöntemi, İMO Teknik Dergi, $6725,417$.

Ersoy M., (2012), Afetler İlişkin Planlama Etkinlikleri ve Sakınım Planlaması 'içinde: ERSOY, M. (ed.) Kentsel Planlama. İstanbul: Ninova Yayınlar1.ss.2-6.

Faccioli E., Pessina V., (2003), Use of engineering seismology tools in ground shaking scenarios, International Geophysics Series, 81, 1031-1048.

Fahjan Y., Pakdamar F., Kara F.İ., Eravcı B., Baykal M., Yenilmez G., Yalçın D., (2015), AFAD-RED Deprem Ön Hasar Tahmin Sistemi, 8. Ulusal Deprem Mühendisliği Konferans1.11-15 Mayıs, İstanbul.

Genç F.N., (2007), Türkiye'de doğal afetler ve doğal afetlerde risk yönetimi, Genel Kurmay Başkanlığ1 Stratejik Araştirmalar Dergisi, 9, 9, 201-225.

Gerdan S., (2014), Determination of Disaster Awareness, Attitude Levels and Individual Priorities at Kocaeli University, Eurasian Journal of Educational Research, 55, 159-176.

İBB, (2009), 1/100.000 Ölçekli İstanbul Çevre Düzeni Planı Raporu, İBB İmar ve Şehircilik Daire Başkanlığı, http://www.ibb.gov.tr/tr-TR/kurumsal/Birimler/SehirPlanlamaMd/Documents/100.000ölçekliçevredüzeniPlanSunum.pdf, [Erişim 23 Ekim 2014]. 
ISDR, (2004), Living With Risk: A Global Review of Disaster Reduction Initiatives, United Nations Publications, Geneva, Switzerland, 429ss.

Işık Ö., Aydınlığlu H.M., Koç S., Gündoğdu O., Korkmaz G., Ay A., (2012), Afet Yönetimi ve Afet Odaklı Sağlık Hizmetleri, Okmeydanı Tip Dergisi, 28, 82-123.

Kalkan E., Gulkan P., (2004), Empirical attenuation equations for vertical ground motion in Turkey, Earthquake Spectra, 20, 853882.

Kızılkanat A., Coşar A., Koçak A., Güney D., Selçuk M.E., Yıldırım M., (2011), 23 Ekim 2011 Van Depremi Teknik İnceleme Raporu, Yıldız Teknik Üniversitesi, http://www.yildiz.edu.tr/ deguney/ytu-van-deprem-rapor.pdf, [Erişim 7 Mayıs 2015].

Kundak S., (2014), Kentsel Risklerin Azalttlmast, İSMEP Rehber Kitaplar Beyaz Gemi Sosyal Proje Ajans1, http://www.guvenliyasam.org/Contents/rehber-kitaplar/KENTSEL.pdf, [Erişim 24 Haziran 2014].

Mcguire R.K., (2001), Deterministic vs. probabilistic earthquake hazards and risks, Soil Dynamics and Earthquake Engineering, 21, 377-384.

Nurlu M., Fahjan Y., Eravcı B., Baykal M., Yenilmez G., Yalçın D., Yanık K., Kara F.İ., Pakdamar F., (2014), Rapid Estimation of Earthquake Losses In Turkey Using AFAD-RED System, 2nd European Conference on Earthquake Engineering and Seismology, Istanbul.

Özçevik Ö., Türk Ş., Beygo C., Taş E., Yaman H., (2007), İstanbul'da deprem odaklı dönüşüm projesinin ana bileşenlerinin analizi: IETT Blokları örneği, ITÜ dergisi /a Mimarlık, Planlama, Tasarım, 6, 81-94.

Özmen B., (2000), İzmit Körfezi Depremi'nin hasar durumu (rakamsal verilerle), Türkiye Deprem Vakfi Deprem Raporu TDV/DR 010-53, http://www.turkiyedepremvakfi.org.tr/pdf/deprem_raporlari_sirali/TDV-DR_010-53.pdf, [Erişim 24 Haziran 2014].

Rossetto T., Elnashai A., (2005), A new analytical procedure for the derivation of displacement-based vulnerability curves for populations of RC structures, Engineering structures, 27, 397-409.

Sadigh K., Chang C.Y., Egan J., Makdisi F., Youngs R., (1997), Attenuation relationships for shallow crustal earthquakes based on California strong motion data, Seismological research letters, 68, 180-189.

Somerville P., Moriwaki Y., (2003), 65 Seismic hazards and risk assessment in engineering practice, International Geophysics, 81, $1065-1080$.

Taşkın B., Tuğsal Ü.M., Hasgür Z., (2014), Deprem Tehlikesine Maruz Türkiye Türü Betonarme Binalar İçin Kırılganlık Eğrilerinin Türetilmesi, AFAD-UDAP Projesi, İTÜ İnşaat Fakültesi, Yapı Malzemeleri Laboratuvarı, İstanbul.

Tercan B., (2005), Deprem Sonras1 Yalova'da Yeniden Yerleşme Süreci, Deprem Sempozyumu, 23-25 Mart, Kocaeli 338-339ss.

Thenhaus P.C., Campbell K.W., (2003), Seismic hazard analysis, Earthquake engineering handbook, 8, 1-50.

Tsai C.H., Chen C.W., (2010), An earthquake disaster management mechanism based on risk assessment information for the tourism industry-a case study from the island of Taiwan, Tourism Management, 31, 470-481.

Türkoğlu H., (2014), Afete Dirençli Şehir Planlama ve Yapılaşma, İSMEP Rehber Kitaplar Beyaz Gemi Sosyal Proje Ajansı, http://www.guvenliyasam.org/Contents/rehber-kitaplar/ADSPY.pdf, [Erişim 24 Haziran 2014].

Wells D.L., Coppersmith K.J., (1994), New empirical relationships among magnitude, rupture length, rupture width, rupture area, and surface displacement, Bulletin of the seismological Society of America, 84, 974-1002.

Whitman R.V., Lagorio H.J., (1998), The FEMA-NIBS methodology for earthquake loss estimation, FEMA Toshihisa Toyoda, 2001.

Youd T., (1991), Mapping of earthquake-induced liquefaction for seismic zonation, Fourth International Conference on Seismic Zonation, August 25th-29th, Stanford University, Stanford, California, USA.

Youd T., Tinsley J., Perkins D., King E., Preston R., (1978), Liquefaction Potential Map of San Fernando Valley, California, Int. Conf. on Microzonation for Safer Construction, San Francisco, ss. 267-278.

Youd T.L., Perkins D.M., (1978), Mapping liquefaction-induced ground failure potential, Journal of the Geotechnical Engineering Division, 104, 433-446. 